\title{
Nutritional and therapeutic importance of Daucus carota- A review
}

\author{
Prof Dr Ali Esmail Al-Snafi \\ Department of Pharmacology, College of Medicine, Thi qar University, Iraq.
}

\begin{abstract}
Phytochemical analysis showed that the root of Daucus carota contained alkaloids, carbohydrates, chlorogenic acid, flavonoids, phenols, essential oil, terpenoid and coumarin. The nutritional analysis of carrot juice showed that the juice contained: protein $1.067 \pm 0.058 \%$, crude fat $0.367 \pm 0.089 \%$, crude fibre $1.167 \pm$ $0.153 \%$, carbohydrates $6.100 \pm 0.346 \%$, many vitamins and minerals. The pharmacological studies revealed that the plant possessed cytotoxic, antioxidant, antidiabetic, antimicrobial, smooth muscle relaxant, hypotensive effect and decrease intraocular pressure, gastro-protective, nephro-protective, hepato-protective, cardioprotective antidepressant memory enhancement, anti-inflammatory, reproductive, wound healing and hear induction and many other effects. The current review highlights the chemical constituents, nutritional and pharmacological effects of Daucus carota.
\end{abstract}

Keywords: constituents, nutritional, therapeutic, pharmacology Daucus carota.

\section{INTRODUCTION:}

The World Health Organization (WHO) estimates that 80 percent of the world population, presently use herbal medicine for some aspect of primary health care [1].Plant showed nutritional and therapeutic benefits including antimicrobial, antioxidant, anticancer, hypolipidemic, cardiovascular, central nervous, respiratory, immunological, anti-inflammatory, analgesic antipyretic and many other pharmacological effects [2-60]. Phytochemical analysis showed that the root of Daucus carota contained alkaloids, carbohydrates, chlorogenic acid, flavonoids, phenols, essential oil, terpenoid and coumarin. The nutritional analysis of carrot juice showed that the juice contained: protein $1.067 \pm 0.058 \%$, crude fat $0.367 \pm 0.089 \%$, crude fibre $1.167 \pm 0.153 \%$, carbohydrates $6.100 \pm 0.346 \%$, many vitamins and minerals. The pharmacological studies revealed that the plant possessed cytotoxic, antioxidant, antidiabetic, antimicrobial, smooth muscle relaxant, hypotensive effect and decrease intraocular pressure, gastroprotective, nephro-protective, hepato-protective, cardio-protective antidepressant memory enhancement, antiinflammatory, reproductive, wound healing and hear induction and many other effects. The current review will highlight the chemical constituents, nutritional and pharmacological effects of Daucus carota.

\section{SYNONYMS:}

Carota sylvestris (Mill.) Rupr., Caucalis carnosa Roth, Caucalis carota (L.) Crantz, Caucalis daucus Crantz, Caucalis glabra Forssk.,Daucus allionii Link,Daucus australis Kotov,Daucus blanchei Reut., , Daucus carota var. brachycaulos Reduron, Daucus carota f. epurpuratus Farw., Daucus carota f. fischeri Moldenke, Daucus carota f. goodmanii Moldenke,Daucus carota subsp. hispidus Masclef, Daucus carota var. pseudocarota (Rouy \& E.G.Camus) Reduron, Daucus carota f. roseus Millsp., Daucus carota f. roseus Farw., Daucus communis Rouy \& E. G. Camus, Daucus communis var. pseudocarota Rouy \& E. G. Camus, Daucus esculentus Salisb., Daucus exiguus Steud., Daucus gingidium Georgi, Daucus glaber Opiz ex Celak., Daucus heterophylus Raf., Daucus kotovii M. Hiroe, Daucus levis Raf., Daucus marcidus Timb.-Lagr., Daucus maritimus With., Daucus montanus Schmidt ex Nyman, Daucus neglectus Lowe, Daucus officinalis Gueldenst. ex Ledeb., Daucus polygamus Jacq. ex Nyman, Daucus scariosus Raf., Daucus sciadophylus Raf., Daucus strigosus Raf., Daucus sylvestris Mill., Daucus vulgaris Neck., Tiricta daucoides Raf [61-62].

\section{TAXONOMIC CLASSIFICATION:}

Kingdom: Plantae; Division: Magnoliophyta; Class: Equisetopsida, Subclass: Magnoliidae; Superorder: Asteranae, Order: Apiales, Family: Apiaceae, Genus: Daucus, Species: Daucus carota [61-63].

\section{COMMON NAMES:}

Arabic: gazar; Chinese: hu luo bo; English: carrot; French : carotte; German: Karotte, Möhre , Mohrrübe; India: gajar ; Italian: carota; Japanese: ninjin; Korean: danggeun, hongdangmu; Portuguese: cenoura; Spanish: zanahoria [62]. 


\section{Distribution:}

Carrot is the one of the major vegetable crops cultivated worldwide. The domesticated types are divided into two groups: the Eastern or Asian carrots (var. atrorubens), with mainly purple and yellow roots; and the Western carrots (var. sativus) with mainly orange roots. Carrots were thought to be domesticated in Afghanistan as the primary centre of diversity and they were spread over Europe, Asia and the Mediterranean area, and the origin of western cultivated carrots were thought to be in the Asia Minor Centre, primarily Turkey [63]. It is now distributed in Africa (Algeria, Libya, Morocco, Tunisia); Asia ( Russian Federation, Kazakhstan, Kyrgyzstan, Tajikistan, Turkmenistan, Uzbekistan, Afghanistan, Pakistan, Iran, Iraq, Palestine, Jordan, Lebanon, Syria, Turkey); Europe (Belarus, Estonia, Lithuania, Moldova, Russian Federation-European part, Ukraine, Austria, Belgium, Czech Republic, Germany, Hungary, Liechtenstein, Luxembourg, Netherlands, Poland, Slovakia, Switzerland, Denmark, Ireland, Norway, Sweden, United Kingdom, Albania, Bosnia and Herzegovina, Bulgaria, Croatia, Greece, Italy, Macedonia, Montenegro, Romania, Serbia, Slovenia, France, Portugal, Spain) [62].

\section{Description:}

The stems are erect and branched, generally about 2, feet high, tough and furrowed. Both stems and leaves are more or less clothed with stout, coarse hairs. The leaves are very finely divided, the lowest leaves considerably larger than the upper; their arrangement on the stem is alternate, and all the leaves embrace the stem with the sheathing base. The blossoms are densely clustered together in terminal umbels, or flattened heads, in which the flower-bearing stalks of the head all arise from one point in rays, each ray dividing to form a secondary umbel, or umbellule of white flowers, the outer ones of which are irregular and larger than the others. The flowers themselves are very small, but from their whiteness and number, they form a conspicuous head, nearly flat while in bloom, or slightly convex, as the seeds ripen, the umbels contract, the outer rays, which are to begin with 1 to 2 inches long, lengthening and curving inwards, so that the head forms a hollow cup hence one of the old popular names for the plant (Bird's Nest). The fruit is slightly flattened, with numerous bristles arranged in five rows. The ring of finely-divided and leaf-like bracts at the point where the umbel springs is a noticeable feature [64].

\section{Traditional uses:}

Daucus carota was cultivated for the enlarged fleshy taproot, eaten as a raw vegetable or cooked in many dishes. Eaten sliced, diced, cut up, or shoe-stringed, carrots were used in many mixed vegetable combinations. They were sold in bunches, or canned, frozen, or dehydrated. They may be baked, sauteed, pickled, and glazed, or served in combination with meats, in stews, roasts, soups, meat loaf or curries. Roasted carrot was used as coffee substitutes. Essential oil was used to flavor liqueurs and perfumes. Seeds were aromatic, carminative, diuretic, emmenagogue, stimulant, and were used for dropsy, chronic dysentery, kidney ailments, worms, as aphrodisiac, nervine tonic, and for uterine pain. Roots were refrigerant and used in infusion for threadworm, as diuretic and eliminating uric acid [65-67]. The ethnobotanical uses of this species also included applications in the treatment of cough, diarrhea, dysentery, cancer, malaria, tumors, as an antiseptic, abortifacient, aphrodisiac, carminative, stimulant, stomachic and tonic [68]. Daucus carota was used by the Ancient Egyptians as a stimulant, carminative, diuretic, anthelmintic and as a decoction for infantile diarrhea [69].

Parts used: Roots, leaves and seeds [70].

\section{Physicochemical characteristics:}

The physicochemical investigation of carrot seed oil revealed: relative density $\left(\mathrm{d}^{20} 20\right)$ : $0.9811 \pm 0.0013$, refractive index $\left(\mathrm{n}^{20} \mathrm{D}\right): 1.473 \pm 0.004$, acidity (oleic,\%): $5.60 \pm 1.13$, peroxide value (meq/kg): $16.0 \pm 2.1$, saponification number 143.6 \pm 12.7 , unsaponifiable matter: $(\mathrm{g} / \mathrm{kg}) 9.3 \pm 1.2$ [71]. The physical and chemical properties of carrot seed (dry matter basis) showed that: moisture \%: $6.41 \pm 0.87$, crude protein $\%: 25.19 \pm 1.13$, crude oil \%: $7.89 \pm 0.68$, crude fibre $\%: 31.99 \pm 2.21$, ash \%: $11.52 \pm 0.14$, Total carbohydrate: $\%: 52.3 \pm 2.13$, $\mathrm{HCl}$ insoluble ash \%: 0.0056 \pm 0.0012 , weight of 1000 seeds/g: $2.68 \pm 0.18$, and essential oil yield \%: $1.01 \pm 0.02$ [72].

\section{Chemical constituents:}

The nutritional analysis of carrot juice showed that the juice contained: moisture $91.100 \% \pm 0.265$, protein $1.067 \pm 0.058 \%$, ether extracts (crude fat) $0.367 \pm 0.089 \%$, ash $1.333 \pm 0.153 \%$, crude fibre $1.167 \pm$ $0.153 \%$, carbohydrates $6.100 \pm 0.346 \%$, specific gravity $1.069 \pm 0.003, \mathrm{pH} \quad 6.233 \pm 0.058$, ascorbic acid $(\mathrm{mg} / 100 \mathrm{~g}) 16.667 \pm 1.332, \mathrm{Ca}^{++}(\mathrm{mg} / 100 \mathrm{~g}) 55.000 \pm 0.000, \mathrm{Fe}^{++}(\mathrm{mg} / 100 \mathrm{~g}) 1.667 \pm 0.153, \mathrm{PO}_{4}(\mathrm{mg} / 100 \mathrm{~g}) 44.333$ \pm 1.155 , thiamine $(\mathrm{mg} / 100 \mathrm{~g}) 0.057 \pm 0.006$, niacin $(\mathrm{mg} / 100 \mathrm{mg}) 0.300 \pm 0.000$, riboflavin $0.100 \pm 0.000$ $(\mathrm{mg} / 100 \mathrm{~g}), \beta$-carotene $2730 \pm 43.589$, colour (out of 10) $2.000 \pm 0.000$ and vitamin A $2805 \pm 6.532$. The mineral analysis of carrot seed cultivated in Turkey showed that it contained (dry matter basis) $(\mathrm{mg} / \mathrm{kg}$ ): Al: 23.31 \pm 2.17 , B: $0.306 \pm 0.073$, Ca: $164.11 \pm 31.02$, Cr: $0.086 \pm 0.011$, Cu: 0.06 \pm 0.01 , Fe: $8.21 \pm 0.93$, K: $180.55 \pm 37.36$, Mg: $15.48 \pm 1.61$, Mn: $0.403 \pm 0.083$, Na: $24.35 \pm 4.39$, Ni: $0.059 \pm 0.008$, P: $75.40 \pm 19.28$, Se: $0.005 \pm 0.001$, V: $0.184 \pm 0.038$ and $\mathrm{Zn}: 0.281 \pm 0.061$ [71-73].Phytochemical analysis of ethanol extract of Daucus carota roots 
extracts showed that it contained alkaloids, carbohydrates, chlorogenic acid, flavonoids, phenols, terpenoid and coumarin [74]. Flavonols (quercetin, kaempferol, rutin or quercetin 3-rutinoside) and flavones (apigenin, luteolin and chrysin) were identified from different parts of carrot [75-77]. Furanocoumarin, 8-Methoxypsoralen and 5methoxypsoralen (0 .01-0.02 pg/g fresh weight) were isolated from the fresh plant. Their concentrations were increased in the diseased plant [78].Daucus carota essential oil yields $3 \%$ for seeds and $2.1 \%$ for leaves. A total of 48 compounds were identified in Daucus carota essential oil of leaves, 46 in seeds essential oil. The essential oil from seeds was predominantly composed of oxygenated monoterpens $(66.08 \%)$ and oxygenated sesquiterpens (16.41\%). The main components were geranyl acetate $(52.45 \%)$, cedrone S $(14.04 \%)$, and asarone (11.39\%). The oil from leaves is mainly composed of hydrocarbon monoterpenes $(64.59 \%)$ and hydrocarbon sesquiterpenes (22.18\%), $\alpha$-pinene (27.44\%), sabinene (25.34\%), germacrene D (16.33\%) [79]. Mojaba et al., mentioned that the leaves of carrot (Daucus carota L. subsp. sativus (Hoffman.) Arcang. from Iran gave $0.2 \%$ (v/w) essential oil. Ninety-one compounds were identified in the essential oil. The main class of the compounds was monoterpenes $(30.0 \%)$, sesquiterpenes $(27.8 \%)$ and phenyl propanes $(26.4 \%)$. The major constituents were transanethole $(23.5 \%)$ and myrcene $(14.5 \%)$ [80].The changes occurring in the essential oil yield and chemical composition of Daucus carota L. subsp. sativus (Hoffm.) Arcang. during flowering and fruiting process were studied. The essential oil yield varied from $0.7 \%$ to $1.8 \%(\mathrm{v} / \mathrm{w})$ during umbel ontogeny. The resulted essential oils contained 34 constituents, forming $94.5-97.9 \%$ of the total compositions. The essential oil composition was characterized by high proportions of monoterpenoids (35.9-81.3\%) and sesquiterpenoids (15.1-62.0\%). Major constituents of the essential oils were carotol (10.2-58.5\%), $\alpha$-pinene (21.2-41.2\%), myrcene $(6.4-14.1 \%)$, limonene $(4.4-12.7 \%)$, and sabinene $(0.2-5.3 \%)$. The results obtained were of significance for determining the most favorable time for harvesting carrot umbels for better yield of quality essential oil [81].The analysis of the essential oil of carrot cultivated in Turkey seed and edible seed oil showed that they contained 34 and 14 components, respectively. The major constituents of seed essential oil were carotol $(66.78 \%)$, daucene $(8.74 \%)$, $(\mathrm{Z}, \mathrm{Z})$ - $\alpha$-farnesene $(5.86 \%)$, germacrene D $(2.34 \%)$, trans- $\alpha$-bergamotene $(2.41 \%)$, $\beta$-selinene $(2.20 \%), \beta$ bisabolene $(1.90 \%)$, bicyclogermacrene $(1.87 \%)$ and $\beta$-caryophyllene $(1.10 \%)$ [72].

In studying the essential oils of the fruits of Daucus carota ssp. maximus, it revealed the presence of at least 19 components. The fruit essential oil consisted chiefly of phenylpropanoids (56.84\%) and sesquiterpene hydrocarbons (40.79\%), accompanied by relatively much smaller amounts of monoterpenes (1.33\%) and oxygenated sesquiterpenes (1.04\%). The leaf and stem oils revealed the presence of at least 40 (leaves) and 21 (stems) components. The leaf essential oil consisted chiefly of oxygenated sesquiterpenes and sesquiterpene hydrocarbons $51.20 \%$ and $25.25 \%$ of the oil composition respectively, as well as relatively smaller amounts of monoterpene hydrocarbons (6.31\%), n-alkanes (4.55\%), monoterpene alcohols $(4.19 \%)$ and a straight chain aldehyde $(3.22 \%)$. The stem oil was dominated by oxygenated sesquiterpenes $(80.05 \%)$ accompanied by relatively small amounts of monoterpenes $(10.07 \%)$ and sesquiterpene hydrocarbons $(6.91 \%)$ [82].

The fatty acid composition of carrot seed oil cultivated in Turkey showed that it contained (mg/100g): palmitic: $10.01 \pm 0.13$, palmitoleic: $0.64 \pm 0.02$, stearic: $2.41 \pm 0.06$, oleic: $0.17 \pm 0.01$, linoleic: $11.82 \pm 1.17$, petroselinic: 59.35 \pm 3.81 , vaccenic: $0.55 \pm 0.01$ and arachidic: $0.81 \pm 0.03$ [72].The essential oils of Daucus carota seeds from ten wild populations spread over northern Tunisia were characterized by a predominance of sesquiterpene hydrocarbons in most samples (22.63-89.93\% of the total oil composition). The main volatile compounds identified were $\beta$-bisabolene (mean content of $39.33 \%)$, sabinene $(8.53 \%)$, geranyl acetate $(7.12 \%)$, and elemicin $(6.26 \%)$. The volatile composition varied significantly across the populations, even for oils of populations harvested in similar areas [83]. The essential oil of the flowering and mature umbels with seeds of wild Daucus carota L. subsp carota from two different sites in Tunisia, contained: eudesm-7(11)-en-4-ol (8.2 - 8.5\%), carotol (3.5 - 5.2\%), sabinene (12.0 -14.5\%), a-selinene (7.4 - 8.6) and 11-alpha-(H)-himachal-4-en-1-beta-ol (12.7 $17.4 \%)$, whereas the oils from Tunis were predominantly composed of elemicin (31.5 - 35.3\%) and carotol (48.0 $55.7 \%$ ) as the main components [84]. The essential oil of Daucus carota subsp carota from Portugal, composed of hydrocarbon monoterpenes $(46.6 \%)$ and oxygenated monoterpenes $(29.5 \%)$, with geranyl acetate $(29.0 \%) . \alpha$ pinene $(27.2 \%)$ and $11 \alpha \mathrm{H}$-himachal-4-en-1 $\beta$-ol $(9.2 \%)$, being the main components [85].The chemical composition of the essential oils from the fruits of Daucus carota var. sativus (yellow carrot) and var. boissieri (red carrot) was determined using GC/FID and GC/MS. 29 and 32 compounds were identified accounting for 96.58 and $96.72 \%$ of the total detected components in the hydrodistilled yellow and red carrot oils, respectively. Yellow carrot fruit essential oil had a lower percentage of monoterpenes representing $2.24 \%$ and containing mainly $\beta$-pinene $(0.52 \%)$ and $\alpha$-limonene $(0.43 \%)$ and oxyegenated monterpenes represented $0.66 \%$ containing mainly linalool $(0.34 \%)$. Red carrot fruit essential oil had higher percentage of monoterpenes representing $3.92 \%$ and containing mainly $\beta$-pinene (1.04\%) and p-cymene (1.01\%) and didn't contain any oxygenated monoterpenes. On the other hand, sesquiterpenes were presented in higher percentage in yellow carrot fruit essential oil, containing mainly carotol (66.7\%), $\beta$-bisabolene $(3.91 \%)$, trans- $\alpha$-bergamotene $(3.41 \%)$, germacrene $(2.34 \%)$ and $\alpha$-curcumene $(2.2 \%)$. Almost the same percentage and different pattern can be noticed for the red carrot fruit 
essential oil [carotol (67.71\%), $\beta$-bisabolene (7.66\%), trans- $\beta$-caryophyllene (4.79\%) and trans- $\alpha$-asarone $(2.33 \%)]$. Only n-nonanal as a non terpene compound was present in yellow carrot fruit essential oil $(0.05 \%)$ [86]. Phytochemical investigation of the fruits of Daucus carota resulted in the isolation of a new sesquiterpene named as daucucarotol. It was the first example for a natural eudesmane sesquiterpene with a hydroxymethyl group located at a methine carbon rater than a usual quaternary carbon in the two fused six-membered ring systems [87]. Daucane-type sesquiterpenes such as as trans-dauc-8-ene-4b-ol, trans-dauca-8,11-diene, dauca-5,8-diene, acora4,9-diene, acora-4,10-diene, carotol, daucol and daucucarotol were isolated from Daucus carota [78, 87-89].

Ahmed et al., isolated four sesquiterpenes daucane esters, one polyacetylene, one sesquiterpene coumarin, and sitosterol glucoside from the roots of the wild Daucus carota ssp carota [90].Extracts of fresh roots and foliage of the garden carrot (Daucus carota) were analyzed for linear furocoumarins (psoralens) compared with standard psoralen, xanthotoxin, bergapten, isopimpinellin, heraclenin, and oxypeucedanin. Results showed that garden carrot (Daucus carota) does not contain these photosensitizing, photomutagenic, and photocarcinogenic chemicals or, if present, they occur at very low levels $(0.5 \mathrm{ppm})$ [91-92]. Carotenoids were responsible for the yellow, orange, and red colors of carrots, while anthocyanins, a class of polyphenolic compounds, were responsible for the color of purple carrots. The main anthocyanins detected in two different black carrots (Daucus carota L. ssp. sativus var. atrorubens Alef L. ssp. sativus var. atrorubens Alef.) cultivars, associated with Antonina and Purple Haze varieties, from Cuevas Bajas (Málaga, Spain), were found to correspond to five cyanidin-based anthocyanins: cyanidin 3-xylosylglucosylgalactoside, cyanidin 3-xylosylgalactoside and the sinapic, ferulic and coumaric acids derivative of cyanidin 3-xylosylglucosylgalactoside. The anthocyanins present in the black carrots were essentially acylated and their levels were found to correspond to 25 and $50 \%$ of the total phenolic content for the purple Haze and Antonina varieties, respectively [93].However, black carrot contained anthocyanin, the content of monomeric anthocyanins, values ranged between 1.5 and $17.7 \mathrm{mg} / 100 \mathrm{~g}$ fresh weight, the major anthocyanins isolated from black carrot (Daucus carota ssp. sativus var. atrorubens Alef.) was Cyanidin 3xylosyl(glucosyl)galactosides acylated, with sinapic acid, ferulic acid, and coumaric acid. Cyanidin 3-xylosyl (sinapoyl glucosyl) galactoside was found to exhibit a lower visual detection threshold and a higher pH stability than cyanidin 3-xylosyl (feruloyl glucosyl) galactoside and cyanidin 3-xylosyl (coumaroyl glucosyl) galactoside [94]. Carrot roots were rich in carotenoids. Six carotenes $(\alpha-, \beta$-, $\gamma$-,and $\zeta$-carotenes, $\beta$-zeacarotene, and lycopene) were separated from typical and dark orange carrots. $\alpha$ - and $\beta$-carotene represented the major carotenoids accounting for 13-40\% and 45-80\% of the carotenoids in orange carrots [95-96].Total phenolics of carrot varaities varied among the cultivars and ranged from 17.9 to $97.9 \mathrm{mg}$ gallic acid equivalents (GAE)/100 $\mathrm{g}$ fresh weight [94]. Twelve polyphenolic compounds were isolated from 70 and $40 \%$ ethanolic extracts of wild Daucus carota included myricetin, chlorogenic acid, luteolin, apigenin, rutin, catechin, ferulic acid, p-coumaric acid, 3hydroxybenzoic acid, hydroxybenzaldehyde, caffeic acid and cinnamic acid. Rutin represented the major component in both extracts [97].The total phenol contents of leaves extract of Algerian wild carrot Daucus carota was (13.83 mg GAE/g) and of the seeds extract was (7.08 $\mathrm{mg} \mathrm{GAE} / \mathrm{g})$ [79].Average content of total polyphenols $(\mathrm{mg} / \mathrm{kg})$ in many carrot varieties was $81.25 \pm 13.11-113.69 \pm 11.57 \mathrm{mg} / \mathrm{kg}$, $\beta$-carotenes $(\mathrm{mg} / \mathrm{kg}) 24.58 \pm 2.38$ $124.28 \pm 3.54$ and the average values of antioxidant activity (\% inhibition) in carrot $6.88 \pm 0.92-9.83 \pm 0.62$ [98] Carrot roots of orange, red, yellow, white and purple color were freeze-dried and analyzed for phenolic content by Folin-Ciocalteu assay and UV/Vis assay. Carrots developing purple roots possessed on average 9 times more phenolics than roots of other colors. Furthermore, they were rich in anthocyanins that caused very high antiradical activity. Red carrots showed higher antioxidant activity than orange, yellow and white carrots and in the season of lower rainfall they accumulated higher amounts of phenolic compounds. Carrots of Asian origin belonging to Eastern gene pool were more often purple or red and richer in phenolics and had higher antiradical activity than those from the Western gene pool with orange roots [99].Three flavones included luteolin, luteolin 3'-O-beta-Dglucopyranoside and luteolin 4'-O-beta-D-glucopyranoside were isolated from the methanol extract of Daucus carota seeds [68].

\section{Pharmacological effects: Cytotoxic effects:}

The effect of Daucus carota fraction, pentane/diethyl ether (50:50), on was investigated in lung, skin, breast and glioblastoma cancer cell motility and invasion. A pronounced decrease in cancer cell motility was observed in the 4 cell lines. The treatment also led to a decrease in cancer cell invasion and an increased cell adhesion. Additionally, the Daucus carota fraction decreased the activation of the $\rho$-GTPases Rac and CDC42, a finding which may partially explain the decrease in cell motility [100]. The cytotoxic effect of Daucus carota oil extract (DCOE) was studied in acute myeloid leukemia (AML) cells. All the AML cell lines tested were sensitive to the extract while peripheral mononuclear cells were not. It appeared that it produced effect via increase in cells positive for annexinV and for active caspases, indicating that DCOE induced apoptotic cell death in AML. Inhibition of the MAPK pathway decreased sensitivity of AML cells to DCOE, indicating that cytotoxicity may be dependent on its activity. The authors concluded that, DCOE induced selective apoptosis in 
AML cells, possibly through a MAPK-dependent mechanism [101].The chemopreventive effects of oil extract from Daucus carota umbels was investigated on 7,12-dimethyl benz(a)anthracene (DMBA)-induced skin papilloma in mice. The extract was administered to animals via gavage $(0.02 \mathrm{ml}$ of $100 \%$ oil $)$, intraperitoneal $(0.3 \mathrm{ml}$ of $2 \%$ oil $)$, and topical $(0.2 \mathrm{ml}$ of 5,50 , and $100 \%$ oil) routes for 20 weeks. Tumor appearance, incidence, yield, and volume were compared with those of a non-treated control group. Topical $100 \%$ treatment delayed tumor appearance, and inhibited tumor incidence and yield by 40 and $89 \%$, respectively. Topical $50 \%$ treatment inhibited tumor incidence and yield by 30 and $83 \%$, respectively, whereas the $5 \%$ treatment inhibited tumor yield by $36 \%$. Tumor volume was decreased by 99,91 , and $70 \%$ following topical treatments with 100, 50, and 5\% oil, respectively. Intraperitoneal treatment inhibited tumor yield by $43 \%$, and decreased tumor volume by $85 \%$, whereas gavage treatment showed minimal effects. Both intraperitoneal and topical treatment decreased infiltration and hyperplasia with an increase in the level of hyperkeratosis [102].

The major flavonoids isolated from the methanol extract of Daucus carota seeds (luteolin, luteolin 3'-Obeta-D-glucopyranoside and luteolin 4'-O-beta-D-glucopyranoside) were tested for cytotoxicity towards brine shrimp. The $\mathrm{LD}_{50}$ value of luteolin was $5.3 \times 10^{-2} \mathrm{mg} / \mathrm{ml}$, and that of its 3'-O-glucoside and 4'-O-glucoside were > $1.0 \mathrm{mg} / \mathrm{ml}$ [68].Falcarinol from carrots at concentrations above $10 \mu \mathrm{M}$ decreased cell proliferation of CaCo-2 cells after 48 and $72 \mathrm{~h}$ [103].The effects of five fractions from carrot juice extract (CJE) [three polyacetylenes (falcarinol, falcarindiol and falcarindiol-3-acetate) and two carotenoids (beta-carotene and lutein)] were studied in human lymphoid leukaemia cell lines. Treatment of all three lymphoid leukaemia cell lines with the fraction from carrot extracts contained polyacetylenes and carotenoids showed that they were significantly cytotoxic. Treatments with purified polyacetylenes also induced apoptosis in a dose and time responsive manner. Falcarinol and falcarindiol-3-acetate isolated from Daucus carota were more cytotoxic than falcarindiol. In contrast, the carotenoids showed no significant effect on either apoptosis or cell proliferation in all investigated cells [104].

The effect of falcarinol was studied in the development of azoxymethane induced colon preneoplastic lesions in male rats. Feeding of rats with freeze-dried carrots containing $35 \mu \mathrm{g}$ falcarinol per gram, or the same dose of falcarinol, delayed the development of tumours and aberrant crypt foci following 18 weeks [105].

The effect of carrot juice extracts was studied in myeloid and lymphoid leukemia cell lines together with normal hematopoietic stem cells. Leukemia cell lines and nontumor control cells were treated with carrot juice extracts for up to 72 hours in vitro. Induction of apoptosis was investigated by using annexin V/propidium iodide staining followed by flow cytometric analysis, the results were confirmed by using 4'-6-diamidino-2-phenylindole morphology. Effects on cellular proliferation were investigated via cell cycle analysis and cell counts. Treatment of leukemia cell lines with carrot juice extract induced apoptosis and caused cell cycle arrest. Lymphoid cell lines were affected to a greater extent than were myeloid cell lines, while, normal hematopoietic stem cells were less sensitive than cancer cell lines [106]. The anticancer effect of Daucus carota oil extract fractions was studied on the human breast adenocarcinoma cell lines MDA-MB-231 and MCF-7. By using of WST assay, the pentane fraction (F1) and 1:1 pentane:diethyl ether fraction (F2) possessed the highest cytotoxicity against both cell lines. Flow cytometric analysis revealed that both fractions induced the accumulation of cells in the sub-G1 phase and increased apoptotic cell death and chromatin condensation. The increase in apoptosis in response to treatment was also apparent in the increase in BAX and the decrease in Bcl-2 levels as well as the proteolytic cleavage of both caspase-3 and PARP as revealed by Western blot. Treatment of MDA-MB-231 cells with either fraction also significantly reduced the level of phosphorylated Erk but did not show any effect on phosphorylated Akt [107]. The anticancer activity of the pentane fraction (F1) and the 1:1 pentane:diethyl ether fraction (F2) of the Daucus carota oil extract was evaluated against human colon adenocarcinoma cell lines (HT-29 and Caco-2). Treatment of cells with various concentrations of F1 or F2 fractions produced a dose-dependent inhibition of cell proliferation. Flow cytometric analysis indicated that both fractions induced sub-G1 phase accumulation and increased apoptotic cell death. Western blot revealed the activation of caspase-3, PARP cleavage, and a considerable increase in Bax and p53 levels, and a decrease in Bcl-2 level. Treatment of HT-29 cells with either fraction markedly decreased the levels of both phosphorylated Erk and Akt [108]. The in vitro anticancer activity of Daucus carota oil extract was evaluated on cell lines using the trypan blue exclusion method and the WST-1 cell proliferation assay. The anticancer activity of the oil extract was evaluated against human colon (HT-29, Caco-2) and breast (MCF-7, MDA-MB-231) cancer cell lines. Oil extract caused significant increase in cell death and decrease in cell proliferation. The effects of the oil on cell lines were time and dose-dependent [109].In cytotoxic investigation of the essential oils from the fruits of Daucus carota var. sativus (yellow carrot) and var. boissieri (red carrot), a highest cytotoxic activity was observed against HepG-2 cell with $\mathrm{IC}_{50}$ values ranging from $163-172 \mu \mathrm{g} / \mathrm{ml}$ for both oils [86].

\section{Antioxidant effect:}

The effects of a 3-week supplementation of the diet with carrot (15\% dry matter) in antioxidant status was studied in rats. Carrot consumption improved the antioxidant status. It significantly decreased the urinary excretion of thiobarbituric acid reactive substances (TBARS), reduced the TBARS levels in heart, increased the vitamin E 
plasmatic level and tended to increase the ferric reducing ability of plasma (FRAP) as compared to the controls. The carrot diet provided carotenoid antioxidants: $5.1 \mathrm{mg} \beta$-carotene, $1.6 \mathrm{mg} \alpha$-carotene and $0.25 \mathrm{mg}$ lutein per 100 $\mathrm{g}$ diet. The three carotenoids were detected in the plasma of the rats fed the carrot diet at $125,41,43 \mathrm{nmol} / 1$ concentrations respectively. $\beta$-Carotene was also detected in liver and heart [110].Antioxidants and antioxidant capacity of seven colored carrots were studied. Antioxidant capacities of the hydrophilic and hydrophobic fractions were determined using 2,2'-azinobis(3-ethylbenzothiazoline-6-sulfonic acid) (ABTS) and 2,2'-diphenyl-1picrylhydrazyl (DPPH) methods. Five anthocyanins, chlorogenic acid, caffeic acid, and four carotenoids were quantified by HPLC. Anthocyanins were the major antioxidants in purple-yellow and purple-orange carrots, and chlorogenic acid was the major antioxidant in all carrots. Both the DPPH and ABTS assays showed that the hydrophilic extract had higher antioxidant capacity than the hydrophobic extract. Purple-yellow carrots had the highest antioxidant capacity, followed by purple-orange carrots, and the other carrots did not significantly differ [111]. The flavones isolated from the methanol extract of Daucus carota seeds (luteolin, luteolin 3'-O-beta-Dglucopyranoside and luteolin 4'-O-beta-D-glucopyranoside) were studied for antioxidant effects. Among these three flavones, luteolin showed the highest degree of free radical scavenging activity $\left(\mathrm{RC}_{50}=4.3 \times 10^{-4} \mathrm{mg} / \mathrm{ml}\right) \mathrm{in}$ the 2,2-diphenyl-1-picrylhydrazyl (DPPH) assay [68]. Digested purple carrot extract exhibited intracellular ROSinhibitory capacity, with $1 \mathrm{mg} / \mathrm{ml}$ showing the ROS clearance of $18.4 \%$. A $20.7 \%$ reduction in oxidative DNA damage due to colon mucosa cells' treatment with digested purple carrot extract was observed [112]. The in vitro antioxidant activity of Daucus carota oil extract (DCOE) was evaluated using 1,1-diphenyl-2-picryl hydrazyl free radical scavenging assay (DPPH), ferrous ion chelating assay (FIC) and the ferric reducing antioxidant power assay (FRAP). DCOE exhibited antioxidant activity in all assays. The FRAP value was $164 \pm 5.5 \mu$ mol for $\mathrm{FeSO}_{4}$ $/ \mathrm{g}$, and the $\mathrm{IC}_{50}$ values for DPPH and FIC assays were $2.1 \pm 0.03 \mathrm{mg} / \mathrm{ml}$ and $0.43 \pm 0.02 \mathrm{mg} / \mathrm{ml}$, respectively [109]. The antioxidant activity of the essential oils from the fruits of Daucus carota var. sativus (yellow carrot) and var. boissieri (red carrot) was investigated using DPPH. Both oils were able to reduce DPPH and to prevent the degradation of the deoxyribose sugar in a concentration dependent manner. Carrot oils showed promising scavenging activity of $\mathrm{DPPH}$ with an $\mathrm{IC}_{50}$ of $12.71 \mathrm{mg} / \mathrm{ml}$ and $14.15 \mathrm{mg} / \mathrm{ml}$ for the yellow and red carrot oils, respectively [86].The antioxidant activity of wild Daucus carota extracts seed (70\% and 40\% ethanol) was investigated. The results indicated that the $70 \%$ ethanolic extract has a higher total phenol and flavonoid content than $40 \%$ ethanolic extract. The antioxidant activity of $70 \%$ ethanolic extract was $86.88 \% \pm 3.018$, whereas, the scavenging activity of $40 \%$ ethanolic extract was $78.72 \% \pm 3.276$ [97]. The n-Hexane, ethyl acetate, and methanol extracts of leaves of Daucus carota were examined for free radical scavenger activity using DPPH method. The compounds possessed antioxidant activity in the n-hexane extract was lutein. The compound at concentration of $0.616,1.025$, and $2.05 \mathrm{ppm}$ had antioxidant activities of $0.94 \pm 0.05,18.53 \pm 0.15$ and $49.07 \pm 0.86 \%$, respectively [113]. The antioxidant features of the black carrot extracts was appeared significantly higher than that of orange carrots, the recorded reducing capacity of two black carrots extracts was $(86.4 \pm 8.0$ and $182.0 \pm 27 \mu \mathrm{M} \mathrm{TE} / 100$ $\mathrm{g} \mathrm{fw})$ and the radical scavenging ability was (17.6 \pm 9.0 and $240.0 \pm 54.0 \mu \mathrm{M} \mathrm{TE} / 100 \mathrm{~g} \mathrm{fw})$ [93].

High-carbohydrate, high-fat diet-fed rats developed hypertension, cardiac fibrosis, increased cardiac stiffness, endothelial dysfunction, impaired glucose tolerance, increased abdominal fat deposition, altered plasma lipid profile, liver fibrosis and increased plasma liver enzymes together with increased plasma markers of oxidative stress and inflammation as well as increased inflammatory cell infiltration. Purple carrot juice reversed all these parameters. Anthocyanins were responsible for the antioxidant and anti-inflammatory properties of purple carrot juice and improvement of glucose tolerance and maintaining cardiovascular and hepatic structure and function, while, $\beta$-carotene did not reduce oxidative stress, cardiac stiffness or hepatic fat deposition [114].

\section{CNS effects:}

The effects of ethanolic extract of Daucus carota seeds on cognitive functions, total serum cholesterol levels and brain cholinesterase activity were studied in mice. The ethanolic extract of Daucus carota seeds (DCE) was administered orally in three doses $(100,200,400 \mathrm{mg} / \mathrm{kg})$ for seven successive days to different groups of young and aged mice. Elevated plus maze and passive avoidance apparatus was used as exteroceptive behavioral models for testing memory. Diazepam-, scopolamine- and ageing-induced amnesia were used as interoceptive behavioral models. DCE $(200,400 \mathrm{mg} / \mathrm{kg}$, po) showed significant improvement in memory scores of young and aged mice. The extent of memory improvement evoked by DCE was $23 \%$ at the dose of $200 \mathrm{mg} / \mathrm{kg}$ and $35 \%$ at the dose of $400 \mathrm{mg} / \mathrm{kg}$ in young mice using elevated plus maze. Significant improvements in memory scores were observed with the using passive avoidance apparatus and aged mice. DCE also reversed the amnesia induced by scopolamine $(0.4 \mathrm{mg} / \mathrm{kg}$, ip) and diazepam (1 mg/kg, ip). Daucus carota extract (200, $400 \mathrm{mg} / \mathrm{kg}$, po) significantly reduced the brain acetylcholinesterase activity and cholesterol levels in young and aged mice. The extent of inhibition of brain cholinesterase activity evoked by DCE at the dose of $400 \mathrm{mg} / \mathrm{kg}$ was $22 \%$ in young and $19 \%$ in aged mice. There was a remarkable reduction in total cholesterol level as well, to the extent of $23 \%$ in young and $21 \%$ in aged animals with this dose of DCE [115]. The effects of Daucus carota seeds was evaluated in memory in rats. The ethanolic extract of Daucus carota (DCE) was administered orally in three doses (100, 200 and 400 
$\mathrm{mg} / \mathrm{kg}$ ) for seven successive days to different groups of young and aged rats. Elevated plus-maze, Hebb-Williams maze and hexagonal swimming pool were used as exteroceptive behavioral models for testing memory. Diazepam, scopolamine- and aging-induced amnesia were used as interoceptive behavioral models. DCE (200 and 400 $\mathrm{mg} / \mathrm{kg}$, po) induced significant improvement in memory of young and aged rats in elevated plus maze, Hebb Williams maze and hexagonal swimming pool. It also reversed the amnesia induced by scopolamine $(0.4 \mathrm{mg} / \mathrm{kg}$, ip) and diazepam $(1 \mathrm{mg} / \mathrm{kg}$, ip). The results clearly indicated that Daucus carota seeds is a promising therapy to improve memory especially in management of Alzheimer patients [116].The antidepressant potential of ethanol root extract of Dacus carota (DC) was studied in different animal models, forced swim test (FST), tail suspension test (TST), apomorphine induced hypothermia (AIH), reserpine induced hypothermia (RIH), 5-HTP potentiation of head twitches (HTPPH) in mice. Fluoxetine $(25 \mathrm{mg} / \mathrm{kg}$ ) was used as a standard drug in FST, TST and HTPPH models and desipramine $(20 \mathrm{mg} / \mathrm{kg})$ as a standard drug in AIH and RIH models. The antidepressant activity of DC $(400 \mathrm{mg} / \mathrm{kg}$ ) was comparable to that of standard drugs [117]. The seeds contained choline, and have been reported to inhibit brain cholinesterase activity, with a possibility to elevate the brain acetylcholine levels via increased synthesis of acetylcholine, which beneficial in cognitive dysfunctions [118-119].

\section{Antimicrobial effects:}

Four sesquiterpenes daucane esters, one polyacetylene, one sesquiterpene coumarin, and sitosterol glucoside isolated from the roots of the wild Daucus carota ssp carota, showed a range of low antibacterial activities against four Gram positive (Staphylococcus aureus, Streptomyces scabies, Bacillus subtilus and Bacillus cereus) and two Gram negative species (Pseudomonas aeruginosa and Escherichia coli) as well as antifungal against Fusarium oxysporum and Aspergillus niger [90].The flavones isolated from the methanol extract of Daucus carota seeds (luteolin, luteolin 3'-O-beta-D-glucopyranoside and luteolin 4'-O-beta-D-glucopyranoside) were evaluated for antibacterial effects. Both luteolin and its 4'-O-glucoside demonstrated bactericidal activity against Staphylococcus aureus and Escherichia coli, MIC $=5.0 \times 10^{-2}-1.0 \times 10^{-1} \mathrm{mg} / \mathrm{ml}$ ). Luteolin also demonstrated antibactericidal activity against Bacillus cereus and Citrobacter freundii $\left(\mathrm{MIC}=5.0 \times 10^{-2} \mathrm{mg} / \mathrm{ml}\right)$. Luteolin 3'-O-glucoside showed bactericidal activity against Bacillus cereus and Lactobacillus plantarum (MIC = $2.5 \times 10^{-1} \mathrm{mg} / \mathrm{ml}$ and $5 \times 10^{-1} \mathrm{mg} / \mathrm{ml}$, respectively) [68].The antimicrobial activity of the essential oils of the flowering and mature umbels with seeds of wild Daucus carota L. subsp. carota from two different sites in Tunisia, were assayed by using the broth dilution method on Escherichia coli ATCC 35218 and Staphylococcus aureus ATCC 43300, and clinical strains of Candida albicans and C. tropicalis $1011 \mathrm{RM}$. The MIC values obtained were all > 2.5\% (v/v) [84].The in vitro antimicrobial activity of essential oils of Daucus carota seeds was evaluated, using the disk-diffusion method, against one Gram-positive (Staphylococcus aureus) and two Gramnegative bacteria (Escherichia coli and Salmonella typhimurium), and a pathogenic yeast (Candida albicans). All tested essential oils exhibited antibacterial and antifungal activities against the assayed microorganisms [83].The antimicrobial activity of the essential oil of Daucus carota subsp carota from Portugal was evaluated against several Gram positive and Gram negative bacteria, yeasts, dermatophytes, and Aspergillus strains. The results showed a significant activity towards Gram positive bacteria ( $\mathrm{MIC}=0.32-0.64 \mu \mathrm{l} / \mathrm{ml}$ ), Cryptococcus neoformans $(0.16 \mu \mathrm{l} / \mathrm{ml})$, and dermatophytes $(0.32-0.64 \mu \mathrm{l} / \mathrm{ml})$. The inhibition of the germ tube formation and the effect of the oil on Candida albicans biofilms were also unveiled. The oil inhibited more than $50 \%$ of filamentation at concentrations as low as $0.04 \mu \mathrm{l} / \mathrm{ml}(\mathrm{MIC} / 128)$ and decreased both biofilm mass and cell viability [85]. The antimicrobial effect of wild Daucus carota extracts seed (70\% and $40 \%$ ethanol) were examined against Gram positive (Staphylococcus aureus ATCC 6538-P, Staphylococcus hyicus - isolated from the soil, Micrococcus luteus - isolated from soil, criptogamic culture of Bacillus subtilis ATCC 6633), Gram negative (Pseudomonas aeruginosa ATCC 9027, Escherichia coli ATCC 8739 and Salmonella Abony CIP- 8039, and Acinetobacter johnsonii - isolated from the environment, Moellerella wisconsensis - isolated from the environment) and fungi (Candida albicans ATCC 10231, Candida utilis Lia-01, Saccharomyces cerevisia ATCC 9763 and Aspergillus brasiliensis ATCC 16404). The extracts were active against bacteria, the MIC against 2 Gram positive bacteria was $1.56-3.125 \mathrm{mg} / \mathrm{ml}$ and against 3 strains of Gram negative bacteria was $3.125-12.50 \mathrm{mg} / \mathrm{ml}$, whereas against 1 strain of yeast was $3.125-6.25 \mathrm{mg} / \mathrm{ml}$ [97]. The essential oil of wild Daucus carota aerial parts at the end of the flowering stage (DCEO) inhibited the growth of Campylobacter jejuni, Campylobacter coli, and Campylobacter lari strains, including one multidrug resistant Campylobacter jejuni. The molecules responsible for the antibacterial activity were identified as (E)-methylisoeugenol and elemicin [120]. A strongest antifungal activity was observed for carotol, the main sesquiterpenic compound in the carrot seed oil, it inhibited the radial growth of Alternaria alternata by $65 \%$ [121].

\section{Gastroprotective effect:}

The therapeutic potential of $50 \%$ ethanol extract from Daucus carota roots (EDC) was studied as antisecretory, gastroprotective, and antacid capacity using experimental rats. Assessment of EDC antisecretory and in vivo antacid capacities was carried out using a pyloric ligation induced ulcer model. The gastroprotective 
effect was assessed with an absolute ethanol induced ulcer model. The integrity of gastric mucosa was evaluated using the estimation of glutathione and gastric mucus level and with histopathological examination of gastric mucosal cells. The effect of the extract on the liver was assessed by measuring serum biochemical parameters. The EDC significantly $(\mathrm{P}<0.01-0.001)$ reduced gastric lesions in both models. It also significantly $(\mathrm{P}<0.05-0.001)$ reduced the volume of gastric content, the total acidity was significantly $(\mathrm{P}<0.05-0.001)$ reduced with the doses of 100 and $200 \mathrm{mg} / \mathrm{kg}$ EDC. The mucus content and glutathione level increased significantly $(\mathrm{P}<0.05)$ in the absolute alcohol-induced ulcer. The EDC also showed in vitro antacid capacity. Histopathological studies further confirmed the effects of EDC by inhibiting congestion, edema, hemorrhage, and necrosis in gastric mucosa [122].

The anti peptic ulcer effects of the aqueous and methanolic extracts of Daucus carota umbels was investigated against ethanol induced gastric ulcer in rats. Aqueous and methanolic extracts showed significant protection against ethanol induced gastric ulcer with a curative ratio of 46.8 and $68.7 \%$, at a dose of $250 \mathrm{mg} / \mathrm{kg}$ body weight, respectively [123]. The gastroprotective potential of the fresh juice extract of the roots of Daucus carota (200 and $400 \mathrm{mg} / \mathrm{kg}$ bw, orally) was studied in gastric ulcerations experimentally induced by pylorus ligation, aspirin and ethanol induced. The Daucus carota extracts were significantly decreased free acidity, total acidity and ulcer index, while it increased the $\mathrm{pH}$ and the mucus content as compared with control. The Daucus carota extract at a dose of $400 \mathrm{mg} / \mathrm{kg}$ produced 60.45, 56.80 and $43.51 \%$ ulceration inhibition when the gastric ulceration were induced by pylorus ligation, aspirin and ethanol, respectively [124]. The gastroprotective effect of $4.08 \mathrm{~g}$ carrot juice administered by feeding tube was studied on the hydrochloric acid concentration in the stomach in aspirininduced Wistar-strain rats. The result of carrot juice consumption together with aspirin shows a statistically significant reduction in $\mathrm{HCl}$ concentration in the stomach $(\mathrm{P}<0.05)$. The result was also significant when compared with Misoprostol [125].

\section{Nephroprotective and hepatoprotective effects:}

The renoprotective activity of Daucus carota root extract was studied in renal ischemia reperfusion injury in rats. Renal pedicles of rats were occluded for 45 minutes followed by 24 hours reperfusion. Six days prior to induction of I/R, groups of rats received petroleum ether extract, fractional methanolic extract and methanolic extract of Daucus carota root $(250$ and $500 \mathrm{mg} / \mathrm{kg}$, orally). Renal ischemia reperfusion caused significant impairment of kidney function. Six day administration of Daucus carota, minimized this effect. Rats with renal I/R showed significantly decreased activity of superoxide dismutase, catalase, and reduced glutathione compared with the sham operated rats. These declining trends were significantly less in the group treated with petroleum ether, fractional methanolic and direct methanolic extract of Daucus carota root compared with those in I/R group. Renal I/R also produced a significant increase in malondialdehyde level, while pretreatment with Daucus carota extracts was associated with a significantly lower malondialdehyde level. Accordingly, Daucus carota extracts exerted renoprotective activity probably by the free radical scavenging activity [126].The protective and curative potential of Daucus carota root extract was also investigated in renal ischemia reperfusion injury in rats. In protective and curative studies, 14 days prior and 14 days after the induction of ischemia/reperfusion (I/R), rats received petroleum ether extract (PEE 250 and $500 \mathrm{mg} / \mathrm{kg}$ ), fractional methanol extract (FME $250 \mathrm{and} 500 \mathrm{mg} / \mathrm{kg}$ ) and direct methanol extract (DME 250 and $500 \mathrm{mg} / \mathrm{kg}$ ) of Daucus carota root, orally, once daily. PEE at a dose of $500 \mathrm{mg} / \mathrm{kg}$ significantly $(\mathrm{P}<0.001)$ reduced the levels of serum creatinine $(0.853-3.090 \mathrm{mg} / \mathrm{dl})$, uric acid (1.300$3.500 \mathrm{mg} / \mathrm{dl}$ ) and urea $(58.26-132.00 \mathrm{mg} / \mathrm{dl})$ compared to disease control. FME at a dose of $500 \mathrm{mg} / \mathrm{kg}$ body weight significantly $(\mathrm{P}<0.001)$ reduced the levels of serum creatinine $(0.960-3.090 \mathrm{mg} / \mathrm{dl})$, uric acid $(1.700-3.500$ $\mathrm{mg} / \mathrm{dl})$ and urea (77.17-132.00 mg/dl) compared to disease control. DME at a dose of $500 \mathrm{mg} / \mathrm{kg}$ body weight significantly $(\mathrm{P}<0.001)$ reduced the levels of serum creatinine $(1.173-3.090 \mathrm{mg} / \mathrm{dl})$, uric acid $(2.267-3.500 \mathrm{mg} / \mathrm{dl})$ and urea $(84.75-132.00 \mathrm{mg} / \mathrm{dl})$ compared to disease control [127].The nephroprotective effects of ethanolic root extract of Daucus carota (200 and $400 \mathrm{mg} / \mathrm{kg}$, po) was studied against gentamicin-induced nephrotoxicity in albino Wistar rats. Nephrotoxicity was induced in rats by intraperitoneal administration of gentamicin (100 $\mathrm{mg} / \mathrm{kg} /$ day) for 8 days. Gentamicin intoxication induced elevated serum urea, BUN, uric acid, and creatinine levels which was found to be significantly $(\mathrm{P}<0.01)$ decreased in a dose-dependent manner in groups received Daucus carota. The nephroprotective effects of Daucus carota were further confirmed by histological observations [128].The hepatoprotective and antioxidant activity of methanolic extract of Daucus carota seeds was studied in experimental rats. Oxidative stress were induced in rats by thioacetamide $100 \mathrm{mg} / \mathrm{kg} \mathrm{sc}$, in four groups of rats (two test, standard and toxic control). Two test groups received Daucus carota seeds extract (DCSE) at doses of 200 and $400 \mathrm{mg} / \mathrm{kg}$. Standard group received silymarin $(25 \mathrm{mg} / \mathrm{kg})$ and toxic control received only thioacetamide. On the $8^{\text {th }}$ day animals were sacrificed and liver enzyme, serum glutamic pyruvic transaminase (SGPT), serum glutamic-oxaloacetic transaminase (SGOT) and alkaline phosphatase (ALP) were estimated in blood serum and antioxidant enzyme, superoxide dismutase (SOD), catalase (CAT), glutathione reductase (GRD), glutathione peroxidase (GPX), glutathione-S-transferase (GST) and lipid peroxidation (LPO) were estimated in liver homogenate. A significant decrease in SGPT, SGOT and ALP levels was observed in all drug treated groups as compared to thioacetamide group $(\mathrm{P}<0.001)$, furthermore, significant $(\mathrm{P}<0.001)$ increase in SOD, CAT, GRD, 
GPX and GST was observed in all drug treated groups as compared with thioacetamide group. However, a significant $(\mathrm{P}<0.001)$ reduction in LPO was observed as compared to toxic control group [129].The effect of carrot extract on $\mathrm{CCl}_{4}$-induced acute liver damage was evaluatedin mice. The extracts significantly lowered the serum levels of glutamate oxaloacetate transaminase, glutamate pyruvate transaminase, lactate dehydrogenase, alkaline phosphatase, sorbitol and glutamate dehydrogenase elevated by CCl4-induction. Extract also decreased the elevated serum bilirubin and urea. The increased activities of hepatic 5'-nucleotidase, acid phosphatase, acid ribonuclease and decreased levels of succinic dehydrogenase, glucose-6-phosphatase and cytochrome P-450 produced by $\mathrm{CCl}_{4}$ were reversed by the extract in a dose-responsive way [130].

The hepatoprotective effect of kaempferol (100 and $200 \mathrm{mg} / \mathrm{kg}$ bw) isolated from Daucus carota leaves was tested in paracetamol induced liver damage of albino rats. Paracetamol induced significant $(\mathrm{P}<0.05)$ increase in liver enzymes along with hepatic necrosis and visible disarrangements in hepatic tissues. Oral treatment with kaempferol reversed all the serum and liver parameters, dose-dependently [131].

\section{Cardiovascular effects:}

Ethanolic extract of Daucus carota at the dose of $10-100 \mathrm{mg} / \mathrm{kg}$ caused a dose-dependent fall in systolic and diastolic arterial blood pressure in normotensive anesthetized rats. These effects were not blocked by atropine $(1 \mathrm{mg} / \mathrm{kg})$. Pretreatment with Daucus carota did not alter the pressor response to norepinephrine indicating that, cardiovascular effects of Daucus carota were independent of cholinergic or adrenergic receptors involvement. In spontaneously beating guinea-pig paired atria, Daucus carota induced a concentration-dependent decrease in force and rate of atrial contractions. In rabbit thoracic aorta, Daucus carota caused inhibition of $\mathrm{K}^{+}$-induced contractions [132]. Fractionation of aerial parts of Daucus carota resulted in the isolation of two cumarin glycosides coded as DC-2 and DC-3. Intravenous administration (1-10mg/kg) of these compounds caused a dosedependent fall in arterial blood pressure in normotensive anaesthetised rats, Both compounds caused dosedependent $(10-200 \mathrm{pg} / \mathrm{ml})$ inhibitory effect on spontaneously beating guinea pig atria as weIl as on the K-induced contractions of rabbit aorta. The results indicated that DC-2 and DC-3 acting through blockade of calcium channels, the effect which may be responsible for the blood pressure lowering effect of the compounds observed in the in vivo studies [133].Aqueous extract of Daucus carota tubers were investigated for inotropic and cardioprotective effects by measuring various biochemical parameters at the test doses of $250 \mathrm{and} 500 \mathrm{mg} / \mathrm{kg}$. Isoproterenol $(5.25 \mathrm{mg} / \mathrm{kg}$ and $8.5 \mathrm{mg} / \mathrm{kg})$ was administered subcutaneously on $29^{\text {th }}$ and $30^{\text {th }}$ day respectively in order to induce myocardial infarction. Cardiac tonicity was estimated by evaluating $\mathrm{Na}^{+} \mathrm{K}^{+}-\mathrm{ATPase} \mathrm{Mg}^{2+}-\mathrm{ATPase}^{2}$ and $\mathrm{Ca}^{2+}$-ATPase levels in heart. The levels of $\mathrm{Na}^{+} \mathrm{K}^{+}$-ATPase and $\mathrm{Mg}^{2+}$-ATPase were decreased and that of $\mathrm{Ca}^{2+}$ ATPase was increased in extract-treated group significantly $(\mathrm{P}<0.001)$. Cardioprotection was assessed by estimating serum aspartate transaminase, alanine transaminase, lipid peroxidase, and lactate dehydrogenase levels and cardiac total protein, lipid peroxidase, and lactate dehydrogenase. The levels altered by isoproterenol were restored significantly by the administration of the extract [134]. High-carbohydrate, high-fat diet-fed rats developed hypertension, cardiac fibrosis, increased cardiac stiffness, endothelial dysfunction, impaired glucose tolerance, increased abdominal fat deposition, altered plasma lipid profile, liver fibrosis and increased plasma liver enzymes together with increased plasma markers of oxidative stress and inflammation as well as increased inflammatory cell infiltration. Purple carrot juice reversed all these parameters [114]. The effects of a 3-week supplementation of the diet with carrot $(15 \%$ dry matter) in lipid metabolism was studied in rats. A significant decrease of cholesterol level in liver $(-44 \% ; \mathrm{p}=0.0007)$ was observed together with a reduction of the level of liver triglycerides $(-40 \% ; \mathrm{P}=0.0005)$. Fecal total steroids excretion increased by $30 \%$ upon feeding the carrot diet as compared to the control. The secretion of bile acids was maintained, whereas the cholesterol apparent absorption was reduced in rats fed carrot diet [110].

\section{Antidiabetic effect:}

A dichloromethane (DCM) extract of carrot roots stimulated insulin-dependent glucose uptake (GU) in adipocytes in a dose dependent manner. Bioassay-guided fractionation of the DCM extract resulted in the isolation of the polyacetylenes falcarinol and falcarindiol. Both polyacetylenes were significantly stimulated basal and/or insulin-dependent GU in 3T3-L1 adipocytes and porcine myotube cell cultures in a dose-dependent manner. Falcarindiol increased peroxisome proliferator-activated receptor (PPAR) $\gamma$-mediated transactivation significantly at concentrations of 3, 10 and $30 \mu \mathrm{M}$, while PPAR $\gamma$-mediated transactivation by falcarinol was only observed at 10 $\mu \mathrm{M}$. Falcarindiol was linked to the ligand binding domain of PPAR $\gamma$ with higher affinity than falcarinol, both polyacetylenes exhibited characteristics of PPAR $\gamma$ partial agonists. Falcarinol was shown to inhibit adipocyte differentiation as evident by gene expression studies and Oil Red O staining, whereas falcarindiol did not inhibit adipocyte differentiation, which indicated that these polyacetylenes showed different modes of action [135]. The effect of the methanol extract of Daucus carota (wild carrot) seeds (100, 200 and $300 \mathrm{mg} / \mathrm{kg}$ bw orally for 6 days), was studied on the serum levels of lipids and biochemical indices of kidney and liver function in streptozocin-induced diabetic (type 1) rats. Administration of Daucus carota seeds extract in diabetic rats for six 
days, at all doses, significantly decreased serum levels of total cholesterol, triglycerides and creatinine. Furthermore, oral administration of extract (200 and $300 \mathrm{mg} / \mathrm{kg}$ ) significantly decreased serum levels of Low density lipoprotein cholesterol, aspartate amino transferase and urea. Also, extract (300 mg/kg) decreased serum level of alanine aminotransferase $(\mathrm{P}<0.05)[136]$.

\section{Antiinflammatory effects:}

The anti-inflammatory effects of the aqueous and methanolic extracts of Daucus carota umbels was studied in acute and chronic inflammation in rats. In acute inflammation, the aqueous and methanolic extracts produced maximum anti-inflammatory activity at doses of 400 and $140 \mathrm{mg} / \mathrm{kg}$ body weight with 90.9 and $58.6 \%$ inhibition, respectively. In chronic inflammation, the same doses showed maximum anti-inflammatory activity with 58 and $44.1 \%$ inhibition, respectively [123]. The essential oil of Daucus carota subsp carota from Portugal. exhibited some anti-inflammatory potential by decreasing nitric oxide production around $20 \%$ in LPS-stimulated macrophages, without decreasing macrophages viability [85]. The ethanolic extract of Daucus carota seeds was investigated for anti-inflammatory and analgesic activity at the doses of 100, 200 and $400 \mathrm{mg} / \mathrm{kg} \mathrm{bw}$, orally. Carrageenan-, histamine- and serotonin-induced paw edema were used to study the effect of extract in acute inflammatory model, while, formaldehyde-induced arthritis was employed as a chronic model in rats. The acetic acid-induced writhing response and formalin-induced paw licking time in the early and late phases of mice were used to assess analgesic activity. The higher doses of the extract (200 and $400 \mathrm{mg} / \mathrm{kg}$, po) inhibiting carrageenan, histamine and serotonin-induced paw edema as well as formaldehyde-induced arthritis successfully. The extract (200 and $400 \mathrm{mg} / \mathrm{kg}$, po) also significantly attenuated the writhing responses induced by an intraperitoneal injection of acetic acid and late phase of pain response induced by an subplantar injection of formalin in mice [137].Daucus carota seed extracts were investigated as Cyclooxygenase (COX) enzymes inhibitor. Compounds, 2,4,5-trimethoxybenzaldehyde, oleic acid, trans-asarone and geraniol were isolated from seed extract. They showed $3.32,45.32,46.15$, and $3.15 \%$ of prostaglandin $\mathrm{H}$ endoperoxide synthase-I (COX-I) inhibitory activity and $52.69,68.41,64.39$ and $0 \%$ prostaglandin $\mathrm{H}$ endoperoxide synthase-II (COX-II) inhibitory activity, respectively at $100 \mathrm{mg} / \mathrm{ml}$. Compound 2,4,5-trimethoxy benzaldehyde showed selectivity towards COX-II enzyme inhibition at $100 \mu \mathrm{g} / \mathrm{ml}[138]$.

\section{Effects on reproductive systems:}

The petroleum ether extract and fraction 5 (fatty acids) of carrot seeds arrested the normal estrus cycle of adult mouse and reduced the weight of ovaries significantly. The cholesterol and ascorbic acid content in ovaries were significantly elevated by the extract and fraction 5 of carrot seeds. A significant inhibition of delta 5,3-betahydroxy steroid dehydrogenase and glucose-6-phosphate dehydrogenase (the two key enzymes involved in ovarian steroidogenesis) were also recorded in mouse ovaries after 15 days of treatment [139].

The petroleum ether, alcoholic, and aqueous extracts of Daucus carota were evaluated for their possible antiovulatory activity in rabbits with copper-induced ovulation. All extracts inhibited ovulation in $40 \%$, or less, of the animals [140].The influence of carrot seed extract (CSE) on spermatogenesis, number and motility of sperms in cauda epididyme was studied in male rats. Administration of CSE caused a significant increase in cauda epididymis sperm reserve compared with the control $\left(28.2 \pm 1.8 \times 10^{6}\right.$ vs. $\left.45.1 \pm 2.0, \times 10^{6}\right)$. The extract also protected testis from the gentamicin-induced necrosis. The CSE administration caused about 3.5-times increase in the LH levels even in spite of receiving $5 \mathrm{mg} / \mathrm{kg} /$ day gentamicin with no significant effect on FSH levels. The testosterone concentrations in the group received $400 \mathrm{mg} / \mathrm{kg}$ CSE were $30 \%$ and $83 \%$ higher than its levels in the control and gentamicin treated group, respectively. Accordingly, CSE can overcome reproductive toxicity of gentamicin and induces spermatogenesis probably through the elevation of testosterone levels [141].

The alcoholic extract of Daucus carota seed was administered at different doses ranging from 50 to $250 \mathrm{mg} / \mathrm{kg} \mathrm{bw}$ after coitus showed a significant dose dependent antifertility effect. The administration of the extract at a lower dose showed anti-implantational activity, whereas higher doses caused fetal resorption. The main effect of the extract appeared to be an abortifacient activity. At higher dose levels, the extract demonstrated an estrogenic nature with a prolonged estrous phase, whereas lower doses showed an antiestrogenic nature and an increase in the percentage duration of the diestrous phase of the estrous cycle. The extract produced neither progestational nor antiprogestational effects [142].

\section{Wound healing effect:}

The soft paraffin based cream containing 1\%,2\% and 4\% w/w of ethanolic extract of Daucus carota (EEDC) root was formulated and evaluated in wound healing activity on excision and incision wound models. Animals treated with topical EEDC cream formulation $(1 \%, 2 \%$ and $4 \% \mathrm{w} / \mathrm{w})$ showed significance decrease in wound area, epithelization period and scar width whereas, the rate of wound contraction was significantly increased $(\mathrm{P}<0.01, \mathrm{P}<0.001$ and $\mathrm{P}<0.001$ respectively) as compared to control group animals in excision wound model. In incision wound model there was significant increase $(\mathrm{P}<0.01$ and $\mathrm{P}<0.001)$ in tensile strength, 
hydroxyproline and protein content of animals treated with topical EEDC cream formulation (2\% and 4\% w/w, respectively). Ethanolic extract of Daucus carota root cream when applied topically did not show any sign and symptoms of skin irritation [143].

\section{Effect on smooth muscles:}

A nitrogen containing tertiary base isolated from the seeds of Daucus carota, the base and its bromide have been studied on smooth muscles of ileum, uterus, blood vessels and trachea of different species of animals. The tertiary base possessed papaverine like nonspecific smooth muscle relaxant and spasmolytic activity, but its activity was found to be about one-tenth of that of papaverine [144].

\section{Effect on intraocular pressure:}

In normotensive rabbits, topical application of Daucus carota seed extract at the concentration of 0.3 , 0.6 and $1.2 \%$ resulted in mean intraocular pressure (IOP) reduction of 19.33. 23.20 and $25.61 \%$ respectively. No significant difference was observed between the change in IOP in 0.6 and $1.2 \%$ extract treated groups, $0.6 \%$ concentration was chosen for further evaluation in rabbits with experimentally elevated IOP. In water loaded rabbits, maximum mean IOP reduction with $0.6 \%$ extract was $29.39 \%$, which was comparable to pilocarpine [145].

\section{Hear induction effect:}

Animal studies were carried out by application of standardized Daucus carota extract in gel formulation to the shaved dorsal skin of albino rats, then histomorphometric analysis was employed to study induction of the hair follicle cycle. The effect of extract on the telogen to anagen transition, the protein expression levels of $\beta$ catenin in hair follicles were determined by immunohistochemistry. The results showed that petroleum ether Daucus carota extract promoted hair growth by inducing the anagen phase. The histomorphometric analysis data indicated that topical application of the extract in gel form induced an earlier anagen phase and prolonged the mature anagen phase, in contrast to control and $1 \%$ minoxidil treated group. Results also revealed an increase in both the numbers and size of hair follicles of the extract treated group. Moreover, the immunehistochemical analysis revealed earlier induction of $\beta$-catenin in hair follicles of the extract-treated group, compared to the control group [146].

\section{CONCLUSION}

The current review discussed the chemical constituents, nutritional, pharmacological, and therapeutic effects of different parts of Daucus carota to be utilize in medical practice as a result of its safety and effectiveness.

\section{REFERENCES}

[1] Davidson-Hunt I. Ecological ethnobotany: stumbling toward new practices and paradigms. MASA J 2000; 16: 1-13.

[2] Al-Snafi AE. Nutritional value and pharmacological importance of citrus species grown in Iraq. IOSR Journal of Pharmacy 2016; 6(8): 76-108. http://www.iosrphr.org/papers/v6i8V1/H0680176108.pdf

[3] Al-Snafi AE. The nutritional and therapeutic importance of Avena sativa - An Overview. International Journal of Phytotherapy 2015; 5(1): 48-56. http://www.phytotherapyjournal.com/File_Folder/4856(phytothearpy).pdf

[4] Al-Snafi AE. Therapeutic properties of medicinal plants: a review of their detoxification capacity and protective effects (part 1). Asian Journal of Pharmaceutical Science \& Technology 2015; 5(4): 257-270. http://www.ajpst.com/File_Folder/257-270(ajpst).pdf

[5] Al-Snafi AE. Therapeutic properties of medicinal plants: a review of plants with hypolipidemic, hemostatic, fibrinolytic and anticoagulant effects (part 1). Asian Journal of Pharmaceutical Science \& Technology 2015; 5(4): 271-284. http://www.ajpst.com/File_Folder/271-284(ajpst).pdf

[6] Al-Snafi AE. Therapeutic properties of medicinal plants: a review of their effect on reproductive systems (part 1). Ind J of Pharm Sci \& Res 2015; 5(4): 240-248. http://www.ijpsrjournal.com/File_Folder/240248.pdf

[7] Al-Snafi AE. Therapeutic properties of medicinal plants: a review of their gastro-intestinal effects (part 1). Ind J of Pharm Sci \& Res 2015; 5(4): 220-232. http://www.ijpsrjournal.com/File_Folder/220232(ijpsr).pdf

[8] Al-Snafi AE. Therapeutic properties of medicinal plants: a review of their antiparasitic, antiprotozoal, molluscicidal and insecticidal activity (part 1). J of Pharmaceutical Biology 2015; 5(3): 203-217. www.jpbjournal.com/doi/OThrYWxhaTE0Nzg1MjM2OQ== 
[9] Al-Snafi AE. Therapeutic properties of medicinal plants: a review of plants with antidiabetic effects (part 1). J of $\quad$ Pharmaceutical $\quad$ Biology $2015 ; \quad$ 5(3): jpbjournal.com/doi/OTlrYWxhaTE0Nzg1MjM2OQ==

[10] Al-Snafi AE. Therapeutic properties of medicinal plants: a review of plants with antifungal activity (part 1). Int J of Pharm Rev \& Res 2015; 5(3):321-327. http://www.ijprr.com/File_Folder/321-327(ijprr).pdf

[11] Al-Snafi AE. Therapeutic properties of medicinal plants: a review of their dermatological effects (part 1). Int J of Pharm Rev \& Res 2015; 5(4):328-337. http://www.ijprr.com/File_Folder/328-337(ijprr).pdf

[12] Al-Snafi AE. Therapeutic properties of medicinal plants: a review of plants with anticancer activity (part 1). Int J of Pharmacy 2016; 6(1): 30-50. http://www.ijpjournal.org/File_Folder/30-50(ijp).pdf

[13] Al-Snafi AE. Therapeutic properties of medicinal plants: a review of plants with anti-inflammatory, antipyretic and analgesic activity (part 1). Int $\mathbf{J}$ of Pharmacy 2016; 6(1): 51-73. http://www.ijpjournal.org/File_Folder/51-73(ijp).pdf

[14] Al-Snafi AE. Cardiovascular effects of Carthamus tinctorius: A mini-review. Asian Journal of $\begin{array}{llll}\text { Pharmaceutical } & \text { Research } & \text { 2015; } & \text { 5(3): }\end{array}$ http://www.ajprjournal.com/zip.php?file=File_Folder/199-207(ajpr).pdf\&id=163\&quat=5.

[15] Al-Snafi AE. Therapeutic properties of medicinal plants: a review of their immunological effects (part 1). Asian Journal of Pharmaceutical Research 2015; 5(3): 208-216. http://www.ajprjournal.com/zip.php?file=File_Folder/208-216(ajpr).pdf\&id=164\&quat=5.

[16] Al-Snafi AE. The pharmacology of Equisetum arvense- A review. IOSR Journal of Pharmacy 2017; 7(2): 31-42. http://www.iosrphr.org/papers/v7i2V1/D0702013142.pdf

[17] Al-Snafi AE. A review on Dodonaea viscosa: A potential medicinal plant. IOSR Journal of Pharmacy 2017; 7(2): 10-21. http://www.iosrphr.org/papers/v7i2V1/B0702011021.pdf

[18] Al-Snafi AE. The pharmacology and medical importance of Dolichos lablab (Lablab purpureus)- A review. IOSR Journal of Pharmacy 2017; $42-30$. http://www.iosrphr.org/papers/v7i2V1/C0702012230.pdf

[19] Al-Snafi AE. Pharmacological and therapeutic importance of Desmostachya bipinnata- A review. Indo Am J P Sci 2017; 4(01): 60-66. http://iajps.com/pdf/january2017/9.Ali\%20Esmail\%20AlSnafi,IAJPS\%202017,4\%20(01),60-66.pdf

[20] Al-Snafi AE. Chemical constituents and pharmacological effects of Eryngium creticum- A review. Indo Am J P Sci 2017; 4(01): 67-73. http://iajps.com/pdf/january2017/10.\%20Ali\%20Esmail\%20AlSnafi,IAJPS\%202017,\%20(01),\%2067-73.pdf

[21] Al-Snafi AE. Therapeutic properties of medicinal plants: a review of medicinal plants with central nervous effects (part 1). Int $\mathbf{J}$ of Pharmacology \& Toxicology 2015; 5(3): 177-192. http://ijpt.org/File_Folder/177-192(ijptorg).pdf

[22] Al-Snafi AE. Medicinal plants with anti-urolithiatic effects (part1). Int J of Pharmacy 2015; 5(2): 98-103. http://www.ijpjournal.org/File_Folder/98-103.pdf

[23] Al-Snafi AE. Medicinal plants possessed anti-inflammatory antipyretic and analgesic activities (part 2)plant based review. Sch Acad J Pharm 2016; 5(5): 142-158. http://saspublisher.com/wpcontent/uploads/2016/06/SAJP-55142-158.pdf

[24] Al-Snafi AE. Medicinal plants affected reproductive systems (part 2) - plant based review. Sch Acad J Pharm 2016; 5(5): 159-174. http://saspublisher.com/wp-content/uploads/2016/06/SAJP-55159-174.pdf

[25] Al-Snafi AE. Medicinal plants with anticancer effects (part 2)- plant based review. Sch Acad J Pharm 2016; 5(5): 175-193. http://saspublisher.com/wp-content/uploads/2016/06/SAJP-55175-193.pdf

[26] Al-Snafi AE. Antiparasitic, antiprotozoal, molluscicidal and insecticidal activity of medicinal plants (part 2) - plant based review. Sch Acad J Pharm 2016; 5(6): 194-207. http://saspublisher.com/wpcontent/uploads/2016/07/SAJP-56194-207.pdf

[27] Al-Snafi AE. Medicinal plants with antidiabetic effects (part 2): plant based review. IOSR Journal of Pharmacy 2016; 6(7): 49-61. http://www.iosrphr.org/papers/v6i7V2/F06724961.pdf

[28] Al-Snafi AE. Medicinal plants with antioxidant and free radical scavenging effects (part 2): plant based $\begin{array}{llllll}\text { review. IOSR Journal Of } & \text { 62-82. }\end{array}$ http://www.iosrphr.org/papers/v6i7V2/G06726282.pdf

[29] Al-Snafi AE. Medicinal plants with antimicrobial activities (part 2): Plant based review. Sch Acad J Pharm 2016; 5(6): 208-239. http://saspublisher.com/wp-content/uploads/2016/07/SAJP-56208-239.pdf

[30] Al-Snafi AE. Medicinal plants with cardiovascular effects (part 2): plant based review. IOSR Journal of Pharmacy 2016; 6(7): 43-62. http://www.iosrphr.org/papers/v6i7V3/E067034362.pdf

[31] Al-Snafi AE. Detoxification capacity and protective effects of medicinal plants (part 2): plant based $\begin{array}{llllll}\text { review. IOSR Journal of } & \text { 63-84. }\end{array}$ http://www.iosrphr.org/papers/v6i7V3/F067036384.pdf 
[32] Al-Snafi AE. Beneficial medicinal plants in digestive system disorders (part 2): plant based review. IOSR Journal of Pharmacy 2016; 6(7): 85-92. http://www.iosrphr.org/papers/v6i7V3/G067038592.pdf

[33] Al-Snafi AE. A review of medicinal plants with broncho-dilatory effect-Part 1. Scholars Academic Journal of Pharmacy, 2015; 5(7): 297-304. http://saspublisher.com/wp-content/uploads/2016/08/SAJP57297-304.pdf

[34] Al-Snafi AE. Medicinal plants with central nervous effects (part 2): plant based review. IOSR Journal of Pharmacy 2016; 6(8): 52-75. http://www.iosrphr.org/papers/v6i8V1/G068015275.pdf

[35] Al-Snafi AE. Immunological effects of medicinal plants: A review (part 2). Immun Endoc \& Metab Agents in Med Chem 2016; 16(2): 100-121. http://www.eurekaselect.com/146338

[36] Al-Snafi AE. Medicinal plants affected male and female fertility (part 1)- A review. IOSR Journal of Pharmacy 2016; 6(10): 11-26. www.iosrphr.org/papers/v6i10V3/C0610031126.pdf

[37] Al-Snafi AE. Antiparasitic effects of medicinal plants (part 1)- A review. IOSR Journal of Pharmacy 2016; 6(10): 51-66. http://www.iosrphr.org/papers/v6i10V3/H0610035166.pdf

[38] Al-Snafi AE. Antimicrobial effects of medicinal plants (part 3): plant based review. IOSR Journal of Pharmacy 2016; 6(10): 67-92. http://www.iosrphr.org/papers/v6i10V3/I0610036792.pdf.

[39] Al-Snafi AE. Chemical constituents and pharmacological effects of Cynodon dactylon- A review. IOSR Journal of Pharmacy 2016; 6(7): 17-31. http://www.iosrphr.org/papers/v6i7V2/D06721731.pdf

[40] Al-Snafi AE. The pharmacological importance of Centaurea cyanus- A review. Int J of Pharm Rev \& Res 2015; 5(4): 379-384. http://www.ijprr.com/File_Folder/379-384.pdf

[41] Al-Snafi AE. The chemical constituents and pharmacological importance of Chrozophora tinctoria. Int J of Pharm Rev \& Res 2015; 5(4): 391-396. http://www.ijprr.com/File_Folder/391-396.pdf

[42] Al-Snafi AE. Chemical constituents and pharmacological importance of Agropyron repens - A review. Research Journal of Pharmacology and Toxicology 2015; 1 (2): 37-41. http://asdpub.com/index.php/rjpt/article/view/244/156

[43] Al-Snafi AE. Medical importance of Cichorium intybus - A review . IOSR Journal of Pharmacy 2016; 6(3): 41-56. http://www.iosrphr.org/papers/v6i3/E0634156.pdf

[44] Al-Snafi AE. Pharmacological importance of Clitoria ternatea - A review. IOSR Journal of Pharmacy 2016; 6(3): 68-83. http://www.iosrphr.org/papers/v6i3/G0636883.pdf

[45] Al-Snafi AE. Medical importance of Anthemis nobilis (Chamaemelum nobilis)- A review. Asian Journal of Pharmaceutical Science \& Technology 2016; 6(2): 89-95. http://www.ajpst.com/File_Folder/8995(ajpst).pdf

[46] Al-Snafi AE. Adonis aestivalis: pharmacological and toxicological activities- A revew. Asian Journal of Pharmaceutical Science \& Technology 2016; 6(2): 96-102. http://www.ajpst.com/File_Folder/96102(ajpst).pdf

[47] Al-Snafi AE. The contents and pharmacology of Crotalaria juncea- A review. IOSR Journal of Pharmacy 2016; 6(6): 77-86. http://www.iosrphr.org/papers/v6i6V2/I066027786.pdf

[48] Al-Snafi AE. The medical importance of Cydonia oblonga- A review. IOSR Journal of Pharmacy 2016; 6(6): 87-99. http://www.iosrphr.org/papers/v6i6V2/J066028799.pdf

[49] Al-Snafi AE. The pharmacology of Crocus sativus- A review. IOSR Journal of Pharmacy 2016; 6(6): 838. http://www.iosrphr.org/papers/v6i6V3/C06630838.pdf

[50] Al-Snafi AE. The contents and pharmacological importance of Corchorus capsularis- A review. IOSR Journal of Pharmacy 2016; 6(6): 58-63. http://www.iosrphr.org/papers/v6i6V3/F06635863.pdf

[51] Al-Snafi AE. The chemical constituents and pharmacological effects of Convolvulus arvensis and Convolvulus scammonia - A review. IOSR Journal of Pharmacy 2016; 6(6): 64-75. http://www.iosrphr.org/papers/v6i6V3/G06636475.pdf

[52] Al-Snafi AE. A review on chemical constituents and pharmacological activities of Coriandrum sativum. IOSR Journal of Pharmacy 2016; 6(7): 17-42. http://www.iosrphr.org/papers/v6i7V3/D067031742.pdf

[53] Al-Snafi AE. Pharmacology and toxicology of Conium maculatum - A review. The Pharmaceutical and Chemical Journal 2016; 3(2):136-142. http://tpcj.org/download/vol-3-iss-2-2016/TPCJ2016-03-02-136142.pdf

[54] Al-Snafi AE. The constituents and pharmacology of Cnicus benedictus- A review. The Pharmaceutical and Chemical Journal 2016; 3(2):129-135. http://tpcj.org/download/vol-3-iss-2-2016/TPCJ2016-03-02129-135.pdf

[55] Al-Snafi AE. Medicinal importance of Colchicum candidum - A review. The Pharmaceutical and Chemical Journal 2016; 3(2):111-117. http://tpcj.org/download/vol-3-iss-2-2016/TPCJ2016-03-02-111117.pdf

[56] Al-Snafi AE. The pharmacological and toxicological effects of Coronilla varia and Coronilla scorpioides: A review. The Pharmaceutical and Chemical Journal 2016; 3(2): 105-114. http://tpcj.org/download/vol-3-iss-3-2016/TPCJ2016-03-03-105-114.pdf 
[57] Al-Snafi AE. Pharmacological activities of Cotoneaster racemiflorus- A review. The Pharmaceutical and Chemical Journal 2016, 3(2):98-104. http://tpcj.org/download/vol-3-iss-3-2016/TPCJ2016-03-0398-104.pdf

[58] Al-Snafi AE. The constituents and pharmacology of Corchorus aestuans: A review. The Pharmaceutical and Chemical Journal 2016; 3(4):208-214. http://tpcj.org/download/vol-3-iss-4-2016/TPCJ2016-03-04208-214.pdf

[59] Al-Snafi AE. The chemical constituents and pharmacological activities of Cymbopagon schoenanthus: A review. Chemistry Research Journal 2016; 1(5):53-61. http://chemrj.org/download/vol-1-iss-52016/chemrj-2016-01-05-53-61.pdf

[60] Al-Snafi AE. Traditional uses, constituents and pharmacological effects of Cuscuta planiflora. The Pharmaceutical and Chemical Journal 2016; 3(4): 215-219. http://tpcj.org/download/vol-3-iss-42016/TPCJ2016-03-04-215-219.pdf

[61] The plant list, a working list of all plant species, Daucus carota, http://www. theplantlist.org/tpl/record/kew-2757936

[62] US National Plant Germplasm System, Daucus carota, https://npgsweb.ars-grin.gov/ gringlobal/taxonomydetail.aspx $? \mathrm{id}=50010$

[63] Win LL. Agronomic characteristics and nutritional quality of carrot (Daucus carota L.) cultivars from Myanmar and Germany as affected by mineral and organic fertilizers. PhD thesis, Faculty of Agricultural Sciences, Georg August University, Göttingen-Germany 2010.

[64] Botanical.com, Carrot, http://www.botanical.com/botanical/mgmh/c/carrot24.html [2016].

[65] Duke JA. Handbook of Energy Crops 1983.

[66] CSIR (Council of Scientific and Industrial Research). 1948-1976. The wealth of India. New Delhi.

[67] Reed CF. Information summaries on 1000 economic plants. Typescripts submitted to the USDA 1976.

[68] Kumarasamy Y, Nahar L, Byres M, Delazar A and Sarker SD. The assessment of biological activities associated with the major constituents of the methanol extract of 'wild carrot' (Daucus carota L) seeds. J Herb Pharmacother 2005; 5(1):61-72.

[69] Van Wyk BE and Wink M. Medicinal plants of the world : an illustrated scientific guide to important medicinal plants and their uses. Portland, Timber Press 2004.

[70] Kumar M. Ethnobotanical studies on some medicinal plants: a review. World Journal of Pharmaceutical Research 2014; 3(8): 342-361.

[71] USDA National Nutrient Database, http://www.nal.usda.gov/fnic/foodcomp/cgi-bin/list_ nut_edit.pl [April 2010].

[72] Özcan MM and Chalchat JC. Chemical composition of carrot seeds (Daucus carota L.) cultivated in Turkey: characterization of the seed oil and essential oil. Grasas Y Aceites 2007; 58 (4): 359-365.

[73] Olalude CB, Oyedeji FO and Adegboyega AM. Physico-chemical analysis of Daucus carota (carrot) juice for possible industrial applications. IOSR Journal of Applied Chemistry 2015; 8(8): 110-113.

[74] Sivanantham S and Thangaraj N. Phytochemical screening, characterization, compound identification and separation from Daucus carota L. Int J Curr Res Biosci Plant Biol 2015; 2(7): 168-172.

[75] El-Moghazi AM et al. Flavonoids of Daucus carota. Planta Med 1980; 40: 382-385.

[76] Dranik LI and Dolganenko LG. Flavonoids of the fruit of Daucus carota. Chemistry of Natural Compounds 1973; 9(5): 635.

[77] Poulin MJ, Bel-Rhlid R, Piché Y and Chênevert R. Flavonoids released by carrot (Daucus carota) seedlings stimulate hyphal development of vesicular-arbuscular mycorrhizal fungi in the presence of optimal CO2 enrichment. J Chem Ecol 1993; 19(10): 2317-2327.

[78] Ceska O et al. Furocoumarins in the cultivated carrot, Daucus carota. Phytochemistry 1986; $25: 81-83$.

[79] Ksouri A, Dob T, Belkebir A, Krimat S and Chelghoum C. Chemical composition and antioxidant activity of the essential oil and the methanol extract of Algerian wild carrot Daucus carota L. ssp carota (L.) Thell. J Mater Environ Sci 2015; 6(3): 784-791.

[80] Mojaba F, Hamedia A, Nickavara B and Katayoun J. Hydrodistilled Volatile Constituents of the Leaves of Daucus carota L. subsp. sativus. Journal of Essential Oil Bearing Plants 2008; 11(8): 271-277.

[81] Verma RS, Padalia RC and Chauhan A. Chemical composition variability of essential oil during ontogenesis of Daucus carota L. subsp. sativus (Hoffm.) Arcang. Industrial Crops and Products 2014; 52: 809-814.

[82] Saad HEA, El-Sharkawy SH and Halim AF. Essential oils of Daucus carota ssp. maximus. Pharmaceutics Acta Helvetiae 1995; 70: 79-84.

[83] Rokbeni N, M'rabet Y, Dziri S, Chaabane H, Jemli M, Fernandez X and Boulila A. Variation of the chemical composition and antimicrobial activity of the essential oils of natural populations of Tunisian Daucus carota L. (Apiaceae). Chem Biodivers 2013; 10(12): 2278-2290. 
[84] Marzouki H, Khaldi A, Falconieri D, Piras A, Marongiu B, Molicotti P and Zanetti S. Essential oils of Daucus carota subsp. carota of Tunisia obtained by supercritical carbon dioxide extraction. Nat Prod Commun 2010; 5(12):1955-1958.

[85] Alves-Silva JM, Zuzarte M, Gonçalves MJ, Cavaleiro C, Cruz MT, Cardoso Sm and Salgueiro L. New claims for wild carrot (Daucus carota subsp. carota) essential oil. Evidence-Based Complementary and Alternative Medicine 2016; http://dx.doi.org/ 10.1155/2016/9045196

[86] Khalil N, Ashour M, Singab AN and Salama O. Chemical composition and biological activity of the essential oils obtained from yellow and red Carrot fruits cultivated in Egypt. IOSR Journal of Pharmacy and Biological Sciences 2015; 10(2): 13-19.

[87] Fu HW, Zhang L and Yi T and Tian JK. A new sesquiterpene from the fruits of Daucus carota L. Molecules 2009; 14(8): 2862-2867.

[88] Dhillon RS, Gautam VK, Kalsi PS and Chabra BR. A new sesquiterpene ether, carota 1,4-b-oxide from the essential oil of the seeds of carrot (Daucus carota). Phytochemistry 1989; 28: 639-640.

[89] Mazzoni V, Tomi F and Casanova J. A daucane-type sesquiterpene from Daucus carota. J Favour Frag 1999;14: 268-272.

[90] Ahmed AA, Bishr MM, El-Shanawany MA, Attia EZ, Ross SA and Pare PW. Rare trisubstituted sesquiterpenes daucanes from the wild Daucus carota. Phytochemistry 2005; 66:1680-1684.

[91] Ivie GW, Beier RC and Holt DL. Analysis of the garden carrot (Daucus carota L.) for linear furocoumarins (psoralens) at the sub parts per million level. J Agr Food Chem 1982; 30: 413-416.

[92] Esatbeyoglu T, Rodriguez-Werner M, Schlösser A, Liehr M, Ipharraguerre I, Winterhalter P and Rimbach G. Fractionation of plant bioactives from black carrots (Daucus carota subspecies sativus varietas atrorubens Alef.) by adsorptive membrane chromatography and analysis of their potential antidiabetic activity. J Agric Food Chem 2016; doi: 10.1021/acs.jafc.6b02292

[93] Algarra M, Fernandes A, MateusN and Casado J. Anthocyanin profile and antioxidant capacity of black carrots (Daucus carota L. spp. sativus var. atrorubens Af.) from Cuevas Bajas, Spain. J of Food Composition and Analysis 2014; 33:71-76.

[94] Montilla EC, Arzaba MR, Hillebrand S and Winterhalter P. Anthocyanin composition of black carrot (Daucus carota ssp. sativus var. atrorubens Alef.) cultivars Antonina, Beta Sweet, Deep Purple, and Purple Haze. J Agric Food Chem 2011; 59(7): 3385-3390.

[95] Simon PW and Wolff XY. Carotene in typical and dark orange carrots. J Agric Food Chem 1987; 35:1017-1022.

[96] Gross J. Pigments in vegetables: chlorophylls and carotenoids. New York: Van Nostrand Reinhold 1991.

[97] Pavlyuk I, Stadnytska N, Jasicka-Misiak I, Górka B, Wieczorek PP and Novikov V. A study of the chemical composition and biological activity of extracts from wild carrot (Daucus carota L.) seeds waste. Research Journal of Pharmaceutical, Biological and Chemical Sciences 2015; 6(2): 603-611.

[98] Bystricka J, Kavalcova P and Musilova J. Carrot (Daucus carota L. ssp. sativus (Hoffm.) Arcang.) as source of antioxidants. Acta Agriculturae Slovenica 2015; 105 - 2: 303 - 311 .

[99] Leja M, Kamińska I, Kramer M, Maksylewicz-Kaul A, Kammerer D, Carle R and Baranski R. The content of phenolic compounds and radical scavenging activity varies with carrot origin and root color. Plant Foods Hum Nutr 2013; 68(2):163-170.

[100] Zgheib P, Daher CF, Mroueh M, Nasrallah A, Taleb RI and El-Sibai M. Daucus carota pentane/diethyl ether fraction inhibits motility and reduces invasion of cancer cells. Chemotherapy 2014; 60: 302-309.

[101] Tawil M, Bekdash A, Mroueh M, Daher CF and Abi-Habib RJ. Wild carrot oil extract is selectively cytotoxic to human acute myeloid leukemia cells. Asian Pac J Cancer Prev 2015; 16(2): 761-767.

[102] Zeinab RA, Mroueh M, Diab-Assaf M, Jurjus A, Wex B, Sakr A and Daher CF. Chemopreventive effects of wild carrot oil against 7,12-dimethyl benz(a)anthracene-induced squamous cell carcinoma in mice. Pharm Biol 2011; 49(9):955-961.

[103] Young JF, Duthie SJ, Milne L, Christensen LP, Duthie GG and Bestwick CS. Biphasic effect of falcarinol on caco-2 cell proliferation, DNA damage, and apoptosis. J Agric Food Chem 2007; 55(3): 618-623.

[104] Zaini RG, Brandt K, Clench MR and Le Maitre CL. Effects of bioactive compounds from carrots (Daucus carota L.), polyacetylenes, beta-carotene and lutein on human lymphoid leukaemia cells. Anticancer Agents Med Chem 2012; 12(6):640-652.

[105] Kobaek-Larsen M, Christensen LP, Vach W, Ritskes-Hoitinga J and Brandt K. Inhibitory effects of feeding with carrots or (-)-falcarinol on development of azoxymethane-induced preneoplastic lesions in the rat colon. J Agric Food Chem 2005; 53(5): 1823-1827.

[106] Zaini R, Clench MR and Le Maitre CL. Bioactive chemicals from carrot (Daucus carota) juice extracts for the treatment of leukemia. J Med Food 2011; 14(11):1303-1312. 
[107] Shebaby WN, Mroueh M, Bodman-Smith K, Mansour A, Taleb RI, Daher CF and El-Sibai M. Daucus carota pentane-based fractions arrest the cell cycle and increase apoptosis in MDA-MB-231 breast cancer cells. BMC Complement Altern Med 2014; 14:387.

[108] Shebaby WN, Bodman-Smith KB, Mansour A, Mroueh M, Taleb RI, El-Sibai M and Daher CF. Daucus carota pentane-based fractions suppress proliferation and induce apoptosis in human colon adenocarcinoma HT-29 cells by inhibiting the MAPK and PI3K pathways. J Med Food 2015; 18(7): 745752.

[109] Shebaby WN, El-Sibai M, Smith KB, Karam MC, Mroueh M and Daher CF. The antioxidant and anticancer effects of wild carrot oil extract. Phytother Res 2013; 27(5): 737-744.

[110] Nicolle C, Cardinault N, Aprikian O, Busserolles J, Grolier P, Rock E, Demigné C, Mazur A, Scalbert A, Amouroux P and Rémésy C. Effect of carrot intake on cholesterol metabolism and on antioxidant status in cholesterol-fed rat. European Journal of Nutrition 2003; 42: 254-261.

[111] Sun T, Simon PW and Tanumihardjo SA. Antioxidant phytochemicals and antioxidant capacity of biofortified carrots (Daucus carota L.) of various colors. J Agric Food Chem 2009; 57(10): 41424147.

[112] Olejnik A, Rychlik J, Kidoń M, Czapski J, Kowalska K, Juzwa W, Olkowicz M, Dembczyński R and Moyer MP. Antioxidant effects of gastrointestinal digested purple carrot extract on the human cells of colonic mucosa. Food Chem 2016; 190: 1069-1077.

[113] Sudewi S, Wahyuono S and Astuti P. Isolation and identification of free radical scavenger from Daucus carota L leaves. Traditional Medicine J ournal 2014; 19(3): 142-148.

[114] Poudyal H, Panchal S and Brown L. Comparison of purple carrot Juice and $\beta$-carotene in a highcarbohydrate, high-fat diet-fed rat model of the metabolic syndrome. British Journal of Nutrition 2010; 104: 1322-1332.

[115] Vasudevan M and Parle M. Pharmacological evidence for the potential of Daucus carota in the management of cognitive dysfunctions. Biol Pharm Bull 2006; 29(6): 1154-1161.

[116] Mani V, Parle M, Ramasamy K and Majeed ABA. Anti-dementia potential of Daucus carota seed extract in rats. Pharmacologyonline 2010; 1: 552-565.

[117] Babu PN, Nagaraju B, Yamini K, Dhananjaneyulu M, Venkateswarlu K and Mubina M. Evaluation of antidepressant activity of ethanolic extract of Daucus carota in mice. J Pharm Sci \& Res 2014; 6(2): 7377.

[118] Gambhir SS, Sanyal AK, Sen SP and Das PK. Studies on Daucus carota Linn. Part I. Pharmacological studies with the water-soluble fraction of alcoholic extract of seeds: A preliminary report. Indian J Med Res 1966; 54: 178-187.

[119] Gambhir SS, Sanyal AK, Sen SP and Das PK. Studies on Daucus carota Linn. Part II. Cholinergic activity of the quaternary base isolated from water-soluble fraction of alcoholic extract of seeds. Indian J Med Res 1966; 54: 1053-1056.

[120] Rossi PG, Bao L, Luciani A, Panighi J, Desjobert JM, Costa J, Casanova J, Bolla JM. and Berti L. (E)methylisoeugenol and elemicin: Antibacterial components of Daucus carota L. essential oils against Campylobacter jejuni. Journal of Agricultural and Food Chemistry 2007; 55: 7332-7336.

[121] Misiaka IJ, Lipoka J, Nowakowska EM, Wieczoreka PP, Mlynarz P and Kafarski P. Antifungal activity of carrot seed oil and its major sesquiterpene compounds. Zeitschrift für Naturforschung 2004; 59: 791 796.

[122] Chandra P, Kishore K and Ghosh AK. Assessment of antisecretory, gastroprotective, and in vitro antacid potential of Daucus carota in experimental rats. Osong Public Health Res Perspect 2015; 6(6):329-335.

[123] Wehbe K, Mroueh M and Daher CF. The potential role of Daucus carota aqueous and methanolic extracts on inflammation and gastric ulcers in rats. Journal of Complementary and Integrative Medicine 2009; 6(1): 1-16.

[124] Khatib N, Angel G, Nayna H and Kumar JR. Gastroprotective activity of the aqueous extract from the roots of Daucus carota L. in rats. International Journal of Research in Ayurveda \& Pharmacy 2010;1(1): 112-119.

[125] Jiin WH, Hidayat EM and Lukman K. Gastroprotective effect of carrot (Daucus carota L.) juice in rat models. Althea Medical Journal 2014;1(1):35-39.

[126] Mital PR, Laxman PJ and Ramesshvar PK. Protective effect of Daucus carota root extract against ischemia reperfusion injury in rats. Pharmacology 2011;1: 432-439.

[127] Afzal M, Kazmi I, Kaur R, Ahmad A, Pravez M and Anwar F. Comparison of protective and curative potential of Daucus carota root extract on renal ischemia reperfusion injury in rats. Pharm Biol 2013; 51(7): 856-862.

[128] Sodimbaku V, Pujari L, Mullangi R and Marri S. Carrot (Daucus carota L.): Nephroprotective against gentamicin-induced nephrotoxicity in rats. Indian J Pharmacol 2016;48(2):122-127. 
[129] Singh K, Singh N, Chandy A and Manigauha A. In vivo antioxidant and hepatoprotective activity of methanolic extracts of Daucus carota seeds in experimental animals. Asian Pac J Trop Biomed 2012; 2(5): 385-388.

[130] Bishayee A, Sarkar A and Chatterjee M. Hepatoprotective activity of carrot (Daucus carota L.) against carbon tetrachloride intoxication in mouse liver. J Ethnopharmacol 1995;47(2):69-74.

[131] Jain PK, Khurana N, Pounikar Y, Patil S and Gajbhiye A. Hepatoprotective effect of carrot (Daucus carota L.) on paracetamol intoxicated rats. International Journal of Pharmacology and Pharmaceutical Technology 2012; 1(2): 17-22.

[132] Gilani A, Shaheen F and Saeed SA. Cardiovascular action of Daucus carota. Archives of Pharmacal Research 1994; 17(3):150-153.

[133] Gilani AH, Shaheeri F, Saeed SA, Bibi S, Irfanullah, Sadiq M and Faiz S. Hypotensive action of coumarin glycosides from Daucus carota. Phytomedicine 2000; 7(5):423-426.

[134] Muralidharan P, Balamurugan G and Kumar P. Inotropic and Cardioprotective Effects of Daucus carota Linn. on isoproterenol-induced myocardial infarction. Bangladesh Journal of Pharmacology 2008; 3: 7479.

[135] El-Houri RB, Kotowska D, Christensen KB, Bhattacharya S, Oksbjerg N, Wolber G, Kristiansen K and Christensen LP. Polyacetylenes from carrots (Daucus carota) improve glucose uptake in vitro in adipocytes and myotubes. Food Funct 2015; 6(7): 2135-2144.

[136] Pouraboli I and Ranjbar B. The effect of Daucus carota seeds extract on lipid profile, LFT and kidney function indicators in streptozocin-induced diabetic rats. International Journal of Plant Science and Ecology 2015; 3(1): 84-87.

[137] Mani V, Gunnam KK and Parle M. Antinociceptive and anti-inflammatory properties of Daucus carota seeds extract. Journal of health science 2006; 52(5):598-606.

[138] Mornin RA, De Witt DL and Nair MG. Inhibition of cyclooxygenase (COX) enzymes by compounds from Daucus carota L. seeds. Phytotherapy Research 2003; 17: 976-979.

[139] Majumder PK, Dasgupta S, Mukhopadhaya RK, Mazumdar UK and Gupta M. Anti-steroidogenic activity of the petroleum ether extract and fraction 5 (fatty acids) of carrot (Daucus carota L.) seeds in mouse ovary. J Ethnopharmacol 1997; 57(3):209-212.

[140] Kapoor M Garg SK and Mathur VS. Antiovulatory activity of five indigenous plants in rabbits. Indian J Med Res 1974; 62(8): 1225-1227.

[141] Nouri M, Khaki A, Azar FF and Rashidi MR. The protective effects of carrot seed extract on spermatogenesis and cauda epididymal sperm reserves in gentamicin treated rats. Yakhteh Medical Journal 2009; 11: 327-333.

[142] Bhatnagar U. Poscoital contraceptive effects of an alcoholic extract of the Daucus carota Linn seed in rats. Clinical Drug Investigation 1995; 9: 30-36.

[143] Patil MVK, Kandhare AD and Bhise SD. Pharmacological evaluation of ethanolic extract of Daucus carota Linn root formulated cream on wound healing using excision and incision wound model. Asian Pacific Journal of Tropical Biomedicine 2012; 2(2): S646-S655.

[144] Gambhir SS, Sen SP, Sanyal AK and Das PK. Antispasmodic activity of the tertiary base of Daucus carota, Linn. seeds. Indian J Physiol Pharmacol 1979; 23(3): 225-228.

[145] Agarwal R, Gupta SK, Srivastava S, Agrawal SS and Saxena R. Lowering of intraocular pressure by topical application of Daucus carota seed extract in rabbits. Indian J Exp Biol 2008;46(7):541-546.

[146] Shukla N, Sridevi G and Gopkumar P. Pharmacological and histochemical screening for Hair growthpromoting activity of Daucus carota herbal gel. RRJPPS 2014; 3(4): 1-5. 